\title{
DE ZWERFTOCHT VAN SULTAN \\ PAKOEBOEWANA II, NA DIENS VLUCHT UIT DEN KRATON TE KARTASOERA, OP 30 JUNI $1742^{1}$
}

DOOR

A. K. A. GIJSBERTI HODENPIJL.

De moord op de Chineezen te Batavia op 9 October 1740 en volgende dagen onder de regeering van den GouverneurGeneraal Adriaan Valckenier, heeft vèrstrekkende gevolgen gehad.

De opstand der Chineezen breidde zich allengs over geheel Java uit; inlandsche regenten spanden met de opstandelingen samen; te Japara, Joana, Demak, Rembang, Tegal, Semarang en Soerabaya hadden bloedige botsingen plaats tusschen Compagnies troepen en goedgezinde Javaansche hoofden met de opstandelingen, die deze plaatsen ernstig bedreigden.

Ook te Kartasoera, aan het hof van sultan Pakoeboewana, begon het te gisten; de vorst kon niet langer weerstand bieden aan de aan de Compagnie vijandige invloeden; ons fort werd na eene flauwe verdediging genomen; de bezetting werd gedwongen tot den islam over te gaan en zij die dit weigerden werden, evenals de meest gehate officieren, onder wie de commandant, kapitein Van Velzen, gedood. ${ }^{2}$

De toestand werd zoo ernstig, dat de Regeering een buitengewone commissie voor de Oostkust van Java noodig achtte, bestaande in den ontvanger-generaal Hugo Veryssel met den oud-opperkoopman Jan Herman Theling, om aldaar de zaken te onderzoeken en te regelen.

Het eenige lichtpunt in die dagen was de trouw der Madoe-

1 Zie De Jonge "Opkomst”, deel IX, blz. LXXXV.

2 Zie hieromtrent J. J. Meinsma, Het Fort te Kartasoera in 1741 (Bijdragen Taal-, Land- en Volkenkunde v. Ned.-Indië Nieuwe Reeks VI (1863) p. 367) en Leupe, Verhaal van het gepasseerde te Kartasoera enz. (Bijdragen, Nieuwe Reeks VII (1864) p. 102). 
reesche vorsten, die hunne hulp aanboden welke dankbaar werd aanvaard. ${ }^{1}$

24 October 1741 gaven commissarissen aan den soesoehoenan kennis van hun komst ter kuste en door de omstandigheden daartoe gedwongen, was hun politiek in den aanvang tegenover dien vorst zeer voorzichtig.

Zij deelden mede dat zij met een sterke troepenmacht te Semarang waren verschenen, niet om den soesoehoenan of diens onderdanen te beoorlogen, maar alleen om de oproerige Chineezen te verdelgen die zich niet ontzagen een gedeelte van 'skeizers landen te verwoesten en ook zelfs 's Compagnies forten te bezetten.

$Z_{\text {ij }}$ hoopten dus dat de vorst als een trouw bondgenoot de Compagnie hierin behulpzaam zoude zijn, waardoor meteen den laster waarmede eenige slechte belanghebbenden den vorst hadden willen bekladden, den kop zoude ingedrukt worden en de Hooge Regeering kon zien dat de sultan zelf nooit deel had gehad in datgene waarvan hij werd beticht.

Bij de nauwe en hechte verbintenis, die altijd tusschen de Compagnie en het huis Amankoerat had bestaan, vertrouwden zij. dan ook dat hij blijken van vriendschap zou blijven geven en trachten weder de rust en vrede aan $\mathrm{Zijne}$ Majesteits onderdanen te bezorgen.

Met geen enkel woord werd gerept van hetgeen met het

1 Welk eene verbittering er heerschte bij de Chineezen en welk lot door hen gemaakte gevangenen te wachten hadden, leert ons eene verklaring 1 November 1741 op het hoofdkantoor te Semarang afgelegd door de Javaansche vrouw Sanko van Kartasoera. Deze vrouw was vijf maanden tevoren van Semarang naar Kartasoera vertrokken en had de catastrophe in den kraton aldaar medio Juli bijgewoond. Zij was met twee Javaansche vrouwen, die bij Europeanen gediend hadden, voor de Chineezen naar Japara gevlucht, alwaar vier Europeesche gevangenen van Rembang werden gebracht „dewelcke seer droevig sijn gemartteliseert snijdende stukken vlees uijt haar lighaam dat in oly gebraden en haar te eeten wierd gegeven, item dat eenige jonge kinderen die van Christe ouders waren mede dusdanig zijn ter dood gebragt."

De inlandsche tegenpartij makte het trouwens niet beter. De Madoereezen versloegen in het laatst van November 1741 de Javanen in Toeban, "wanneer de ged.to regent sig gevangen gaf en alle zijne schatten aanthonen moest, Item sijne pieken te zaamen binden waarna deszelvs vrouwen nakent wierden uijtgekleet in zijn presentie, hetwelk hem zoodanig deed verbitteren dat hij amok speelde maar door de Madureezen met pieken dood gestoken desselvs hoofd afgesneden en aan den Prins gebragt, die het nevens de relatanten na Soerabaya zond." 
fort en zijne bezetting op 20 Juli daaraan voorafgaande was voorgevallen; evenmin van de ongeveer $180 \mathrm{nog}$ in leven zijnde Compagniesdienaren die tot den islam waren overgegaan en bij onderscheidene hofgrooten waren gehuisvest, alwaar zij verschillende diensten verrichtten. De commissarissen handel den aldus omdat het hun bekend was dat de vorst niet de hoofdschuldige was van den ontredderden toestand, maar de aanzienlijkste personen aan het hof (in de eerste plaats de rijksbestierder raden aria Nata Koesoema) die met den vijand heulden. Dit was hun onder meer gebleken uit een onderschepten brief van den rijksbestierder, gericht aan het hoofd der Chineesche rebellen te Oenarang en waarin het volgende voorkwam:

-Door den soesoehoenang is vastelijk besloten de Compagnie te onderwerpen en de Chinesen aan te nemen dog de soesoehoenang toond de Comp. nog Respect maar met een uijterlijke schijn alleen en om dat Ulieden daarvan niet onkundig zal sijn heeft mij de vorst bevolen Ulieden sulkx te schrijven. Dierhalven sal Ul. met al sijn volk moeten afsacken na Samarang om spoedig een Einde met die logie te maken waarna den soesoehoenang yder na merite sal beloonen......

Op den $7^{\text {en }}$ en $9^{\text {en }}$ November 1741 behaalde de Compagniestroepen belangrijke voordeelen op den vijand die Semarang omklemd hield en waarvan op laatstgemelden datum door commissarissen aan den soesoehoenan werd kennis gegeven.

Zij gaven bij die gelegenheid aan den vorst hun verbazing te kennen wegens het groote getal Javanen die zich achter de Chineezen bevonden en ten strijde schenen toegerust te zijn, doch in stede van den algemeenen vijand, de Chineezen, van achteren aan te tasten, de vlucht namen, 't geen de Compagnie zeer vreemd voorkwam; zelfs waren eenige Javaansche vaandels door de onzen vermeesterd. De vorst werd daarop nogmaals aangemaand de oogen te openen voor de toekomstige ellende van land en onderdanen, nu het nog tijd was tot inkeer te komen en geen aandacht te schenken aan hen die verwijdering tusschen hem en de Compagnie trachtten te verwekken, terwijl hem de verzekering werd gegeven dat deze hem nog altijd met open armen zou ontvangen en hem nimmer zou misleiden of bedriegen.

Te gelijkertijd werd aan de ratoe Amankoerat, de moeder 
van den vorst, die veel invloed op dezen had, een schrijven gericht waarin ook haar voor oogen werd gesteld de poel van ellende waarin Java op het punt stond gestort te worden en haar werd medegedeeld dat de vijand zelfs van plan was den vorst van den troon te stooten. Slechts de liefde van de Compagnie voor de Mataramsche kroon noopten commissarissen de ratoe dit klaar en duidelijk onder het oog te brengen.

Op dezen, noch op den vorigen brief werd antwoord ontvangen, doch twee dagen later, op den $11^{\text {en }}$ Nov. 1741 behaalden Compagniestroepen weder een belangrijke overwinning op de Chineezen, waardoor dezen met een aanzienlijk verlies aan menschen en geschut moesten terugtrekken en geheel Semarang werd ontzet.

Ook hiervan werd aan den sultan kennis gegeven. Den $22^{\text {en }}$ November werd eindelijk een schrijven van den soesoehoenan ontvangen maar niet in antwoord op de hiervorenbedoelde brieven doch naar aanleiding van eene schriftelijke mededeeling van commissarissen aan den rijksbestierder Nata Koesoema over de pas geleverde gevechten en over den toestand van het Javaansche rijk.

De eerste brieven waren door den vorst niet ontvangen, maar volgens commissarissen door den rijksbestierder onderschept, die echter, nu de zaken begonnen tegen te loopen, niet langer durfde te zwijgen.

De vorst beschuldigde den commandeur Visscher en den commandant Van Velzen van den verwarden toestand en was blijkbaar op den eersten fel gebeten, omdat deze de hulp van den pangeran Tjakraningrat van Madoera, zijn aartsvijand, had ingeroepen, wiens overwinningen in het oosten van Java hem den schrik om het hart deden slaan.

Tevens had hij zich geërgerd over het wantrouwen van kapitein Van Velzen, die soms met geladen pistolen in den zak in den kraton kwam en des nachts met andere Javaansche hoofden overleg pleegde. ${ }^{1}$

1 Deze hoofden waren de pangerans Toppo Somo en Wiera Mangala, zoons van soenan Mas, die op Ceylon in ballingschap was overleden. Na het overlijden van hun vader vergunde de Regeering hen naar Java terug te keeren, alwaar zij te Kartasoera met den sultan op een gespannen voet leefden. Tijdens de woelingen in den kraton in Juli 1741 werden beide broeders op last van den sultan gedood. 
Maar noch van den moord op dezen gepleegd, noch van 't geen met de bezetting van het fort was voorgevallen, waar en in welken toestand zich de overblijvenden bevonden, werd melding gemaakt.

De vorst verklaarde verder dat hij zich zeer verheugde dat de Compagnie hem nog genegen was en verzocht als blijk daarvan eenig schrijven van de Regeering te Batavia te mogen ontvangen.

Commissarissen draalden niet met hun antwoord; reeds den volgenden dag, 23 November, deelden zij aan $\mathrm{Zijne}$ Majesteit mede, dat zij 's vorsten aangename letteren met de gewone plechtigheden in ontvangst hadden genomen en tot hun leedwezen hadden vernomen hoe de kapitein Van Velzen het misnoegen van het hof had opgewekt. $\mathrm{Zij}$ twijfelden niet, dat wanneer de vorst zich over dien officier bij de Regeering had beklaagd, hij alle mogelijke genoegdoening zou gekregen hebben.

Intusschen zouden commissarissen het ongenoegen van den vorst aan de Regeering te Batavia mededeelen evenals den afval van den Madoereeschen pangeran.

Zij hoopten dat Mataram en de Compagnie nu slechts één lichaam zouden vormen, en twijfelden niet of de Javanen zouden medewerken om de Chineezen te verdelgen. Verder werd aangeraden een brief tot de Hooge Regeering te richten, 't geen voorzeker goed zou opgenomen worden.

Kort daarna deelde de soesoehoenan mede dat wel is waar voldoende bekend was, dat de Compagnie genoegdoening verschafte indien daartoe gegronde reden bestond, maar wat 't gebeurde met den kapitein Van Velzen betrof, had hij door den schielijken opstand en door de slechte raadgevers, geen kans gezien zich te beklagen; weshalve hij verzocht om godswil toch 'tgeen voorbij was te laten rusten, voor de toekomst belovende dat zoo iets nimmer meer zoude geschieden en verzocht tevens met nadruk, dat zijn erfvijand, de Madoereesche prins, die in het oosten het eene gewest na het andere veroverde, weer naar zijn land zou terugkeeren.

Door den tegenspoed der vijandelijke wapens en de angst van den soesoehoenan voor het opdringen der Madoereezen, had men dus weer voeling gekregen met het hof van Mataram en door een beleidvol en bedaard optreden slaagde de Compagnie er in den band die zoo verslapt was, allengs weer hechter aan 
te halen, zoodat ten slotte van alle strijdende partijen de Compagnie de eenige was die voordeelen verkreeg; hoe belangrijk deze waren blijkt uit het contract dat juist een jaar later, 11 November 1743, door den soesoehoenan en de Indische Regeering gesloten werd. ${ }^{1}$

Alvorens de vorst echter deze, voor hem zoo vernederende verbintenis sloot, zou hij nog een langen lijdensweg moeten doorloopen.

Was tot dusverre zooals we gezien hebben, nog geen enkel verwijt gericht tot den soesoehoenan betreffende het gebeurde met de bezetting en het fort te Kartasoera, commissarissen achtten nu het oogenblik gekomen daarover het noodige met den sultan te bespreken, nu zij bemerkten in welk eene verlegenheid de partij aan het hof was gekomen.

7 December 1741 schreven $\mathrm{zij}$ aan den vorst, in antwoord op zijn laatsten brief, dat zij toch hunne verwondering moesten betoonen dat de kwaadsprekers zooveel vermogen op hem hadden gehad en hij zoo eensklaps alle weldaden had vergeten, die hij en zijn geslacht van de Compagnie hadden genoten, door zich in een oorlog te wikkelen, even ongegrond als onrechtmatig en waarvan de uitslag hem niet onzeker kon zijn.

Daar zij echter wisten welke schadelijke gevolgen door slechte raadgevers die, door in troebel water te visschen, slechts hun eigen belang op het oog hadden, kunnen teweeggebracht worden, konden zij dit Zijne Majesteit nog vergeven, maar volkomen onbegrijpelijk kwam het hun voor, hoe het mogelijk was geweest, dat de vorst had kunnen dulden, dat 's Compagnies vestiging te Kartasoera, nagenoeg onder het oog van den soesoehoenan was verwoest en met den grond gelijk gemaakt, een zaak die, vermeenden zij, door de Hooge Regeering zeer hoog zou worden opgenomen en niet zonder reden.

Daar zij tevens veronderstelden, dat die bezetting zich bij den vorst in krijgsgevangenschap bevond, verzochten zij dat die gevangenen met de eerste gelegenheid naar Semarang zouden worden opgezonden er niet aan twijfelende, of zij waren behandeld geworden op de wijze, zooals bij beschaafde volken de gewoonte was, waarvan onlangs nog de Hooge Regeering een voorbeeld had gegeven bij de overbrenging van het lijk van

1 Zie De Jonge „Opkomst enz." deel IX blz. 434.

Dl. 74 
den in 1734 naar Ceylon verbannen pangeran Mangkoe Nagara en van het lijk van den in Gale overleden kipandji Soerengrana, in 1723 van Soerabaya naar dat eiland in ballingschap gezonden. Hun weduwen met familie en gevolg bestaande uit 77 personen waren te Batavia als in vredestijd ontvangen en onthaald geworden, terwijl de jonge prins, zoon van gemelden Mangkoe Nagara met zijn familie, nevens het overige gezelschap, in een woning van het kasteel waren gehuisvest, uithoofde van zijn vorstelijke geboorte met een schildwacht voor de deur. Inderdaad, zoo voegden commissarissen hieraan toe, eene behandeling zoo zachtzinnig en menschlievend, dat de allerwreedste menschen daarover versteld moesten staan, vooral in een tijd dat de Compagnie veel reden tot klagen en misnoegen had; wilde de vorst een goeden raad aannemen dan werd hem aanbevolen betreffende de misdaden der Javanen en het verwoesten van de vasting, asen de Regeering te Batavia excuus te vragen, onder aanbieding van eene zoodanige vergoeding, als de Compagnie zou komen te vorderen.

Om vooral aan dit laatste betoog eenige klem bij te zetten, gaven zij tegelijker tijd aan de ratoe Amankoerat, ten antwoord, dat zij "moeder» zeer verplicht waren voor de openhartigheid waarmede zij de begane feilen had bekend waarom zij haar nu mededeelden dat de Hooge Regeering te Batavia veel meer behagen zou scheppen in zulke oprechte en rondborstige belijdenis, dan in geveinsde en verdachte uitvluchten, zoodat zij hoopten, dat de keizer ook in dien geest zich tot de Regeering zou wenden en als dat reeds geschied was, 't zeer, zeker een goeden indruk zou teweeg brengen.

In een op nederigen toon gesteld schrijven aan de Indische Regeering, betuigde de vorst dan ook dat hij en zijne regenten, "veelvuldige vouten" hadden begaan en vroeg hij pardon voor zich en zijn onderdanen; "'s-Compagnies loge was alleenlijk verwoest door de verbouwereertheijt der Javaansche Volckeren (waaraan zij een grooten voute hadden begaan), maar thans wenschte hij slechts dat het bondgenootschap tusschen hem en de Compagnie, als vroeger mocht onderhouden worden en dat hij tot bewijs daarvan een brief van "grootvader» en Heeren Raden van Indië zou mogen ontvangen, opdat «ik benevens alle mijne onderdanen tot Java mijn vrijelijk mag gerusten».

$\mathrm{Nu}$ was de Compagnie gekomen tot het punt waar men wilde 
zijn en werd aan commissarissen bij een instructie van 30 Dec. 1741 voorgeschreven op welke voorwaarden dat bondgenootschap met den sultan weer kon vernieuwd worden. (Bijlage I).

Art. 2 van die instructie luidde:

"Van den soesoehoenang te eijsschen de restitutie van alle de militairen en verdere dienaren van d'Ed comp. met en benevens derzelver vrouwen en kinderen, dewelke haar met den aanvang van den Jongsten oorlogh in de Cartasourasche vesting en elders mogten hebben bevonden en alsnog in levenden lijve mitsgaders onder zijn $\mathrm{Hoogh}^{\text {ts }}$. maght te vinden zijn schoon dat deselve ofte. Eenige van haar ongenegene moghten bevonden worden om tot d'E. comp. weder over te komen waaraan geen het minste gehoor zal mogen verleend maar dezelve gerestitueerd moeten werden sonder daaromtrent eenigsints in gebreeken te blijven \%.

Zooals we gezien hebben hadden commissarissen echter reeds te voren aan den soesoehoenan verzocht die bezetting naar Semarang terug te zenden, doch de vorst wenschte die gaarne te houden en zelfs aangevuld te krijgen met de ontbrekende officieren en manschappen. Hij wilde die menschen niet gevangen houden maar als weleer tot een bewaking van het hof doen dienen, omdat hij begreep dat door den verwarden toestand van zijn rijk die bezetting hem van persoonlijk nut kon zijn.

Hij liet daarom de verschillende militairen met hun gezinnen weder bij elkaar in barakken in 's Compagnies tuin logeeren; de manschappen werden van nieuwe kleeren voorzien, hunne wapens werden hun teruggegeven en dagelijks werd hun tot onderhoud verstrekt 4 "koebeesten» en 240 pond rijst met de noodige toespijzen. Verder moest de eenige luitenant bij dat detachement aanwezig, evenals weleer de commandant, op zoogenaamde Keizerdagen aan het hof verschijnen.

Maar al deze gunstbewijzen en het herhaald verzoek de bezetting te mogen houden konden geen veranderingen brengen in 's Compagnies zienswijze. "Die arme menschen zijn zoolang krijgsgevangen geweest en daarom is het billijk dat zij voor een tijd volkomen vrij zijn», de vesting is ten eenenmale verwoest, waarom wij $\mathrm{u}$ verzoeken hen zoo spoedig mogelijk te doen vertrekken, schreven commissarissen. Kort daarop, 20 Januari 
1742 , werd de bezetting bestaande uit 180 Europeanen ${ }^{1}$ met hunne gezinnen onder geleide van een paar voorname hofgrooten te Semarang aangebracht.

Het vertrek der Europeesche militairen had den angst en de zorg van den vorst dermate vergroot, dat hij bij herhaling verzocht toch weer een nieuwe lijfwacht te mogen ontvangen zooals dat bij het leven van zijn vader en zijn grootvader het geval was geweest, en daarmede niet te wachten tọt het fort weer opgebouwd zou zijn "vermits ik ten uijttersten bevreesd ben doordien ik mij op niemant kan vertrouwen. Ook zijn moeder, de ratoe, herhaalde deze bede, voorgevende dat uit het vertrek der Europeanen de Javaan zou opmaken dat de Compagnie geen liefde of genegenheid meer voor den sultan en zijn familie had. Voor den opbouw der vesting waarvoor de materialen reeds waren bijeengebracht werd de onverwijlde toezending verzocht van een architect of ingenieur, die de noodige aanwijzingen daarbij kon geven.

Commissarissen gaven ten antwoord dat hierover de Hooge Regeering moest beslissen, doch op het aanhouden van een afgezant van den vorst (die voor een aanval van den vorst van Madoera vreesde), om als het niet mogelijk was een Europeesche wacht bij den sultan te plaatsen, dan een paar gecommitteerden te zenden, die hem met raad en daad konden ter zijde staan, besloten zij aan dien wensch gevolg te geven, om zooals zij aan G. G. en Raden van Indië te kennen gaven, «alle wantrouwen weg te nemen als tot voorkominge der sinistre intrigues van Sing Seck ${ }^{2}$ met zijn Javaansche aanhang, mitsgaders door eene nauwe correspondentie agter de geheime van het Cartasoerase Hoff te komen, daar wij door het oproepen der oude besettelingen ten Eenemaal van verstoken sagen.

Kapitein Johan Andries baron van Hohendorff bleek genegen de hachelijke commissie te aanvaarden; hij was meermalen aan het Hof geweest en bij keizer en hofgrooten zeer

1 Te weten: 1 luitenant, 3 vaandrigs, 1 oppermeester, 1 negotieboekhouder, 2 assistenten, 1 baas timmerman, 1 krankbezoeker, 4 ondermeesters, 1 koetsier, 1 trompetter, 4 ambachtslieden, 10 sergeanten, 15 korporaals, 2 tamboers, 122 gemeene soldaten, 1 constabel, 1 constabelmaat, 3 matrozen en 1 vrijburger.

2 Het hoofd der Chineesche opstandelingen. 
gezien; als tweede werd hem toegevoegd de vaandrig Ferdinand Carel Hogewits, "een zeer beschijden officier» benevens de assistent Balthazar Toutlemonde, die de Javaansche taal eenigermate machtig was, als tolk en secretaris. Opdat zij met eenigen luister aan het Hof zouden kunnen verschijnen werden hun, behalve hun oppassers, nog een korporaal en zes soldaten toegevoegd. In de instructie, gedateerd 13 Maart 1742, werd aan Van Hohendorff voorgeschreven dat hij niet naar Cartasoera werd gezonden om in eenige onderhandeling te treden met den soesoehoenan of zijn ministers omtrent de gepasseerde zaken of de vrede "dewijl wij die voor ons zelf gereserveerd houden", maar alleen op verzoek en tot geruststelling van den vorst die een inval vreesde van Madoereezen en Chineezen in zijn gebied en om de kwaaddenkenden, die veronderstelden dat door het oproepen der Kartasoerasche bezetting de Compagnie niets meer met den vorst wilde te maken hebben, van het tegendeel te doen blijken. Hij moest inlichtingen inwinnen betreffende de handelingen van den Madoereeschen vorst en de beweging van diens leger; nagaan of de rijksbestierder Nata Koesoema bedektelijk met den vijand in verbinding stond, of de keizer een volkomen vertrouwen in hem stelde, welke zijne favorite vrouw was en deze trachten uit te hooren, waarbij hij zich van het uitdeelen van geschenken bedienen kon, waartoe hem het geld werd medegegeven.

Over het gebeurde betreffende den moord op den kapitein Van Velzen en het verwoesten van het fort, mocht niet gesproken worden en hij moest indachtig zijn dat hij slechts gezonden was om te hooren en te zien en zich verder met niets mocht bemoeien. ${ }^{1}$

1 De hartstochtelijke vorst van Madoera, pangeran Tjakraningrat, kon zich met deze politiek van de Compagnie in 't geheel niet vereenigen, getuige een mededeeling van de gecommitteerden bij dien vorst aan commissarissen te Semarang, gedateerd Soerabaya, 20 Mei 1742, waarin de "aanstootelijke" woorden van den prins worden aangehaald; ${ }_{n}$ dat het best was, alles te winnen of alles te verliezen, ook den keyser de kop wel wilde afhakken en de raden Adi Patty Natta Coesoema wel eens wilde onder d'oogen sien, dat d'E. Comp naar Cartasoera instede van gecommitteerden en weijnige gemeene, 2000 Europese en Inlandse coppen moest hebben gezonden, die wat uijtvoeren konnen tegens de Chinesen als die daar eens quamen, dog de heeren commissarissen weten dat beter als ik, want ik ben maar kleijn en schrijft aan de Heeren Commissarissen dat ik een Generaal op Batavia heb, en die zijn ordres zal ik nakomen." 
Den $14^{\text {en }}$ Maart 1742 vertrokken Van Hohendorff met de zijnen en kwamen den $17^{\text {en }}$ d. a. v. te Kartasoera aan.

Van Banjoedana op ongeveer 7 K. M., halfweg Bojalali, van de hofplaats gelegen, werd de commissie afgehaald door een tweetal daartoe afgevaardigde radens en onder gevolg van eenige duizenden Javanen naar de paséban geleid, alwaar zij door den rijksbestierder adipati Nata Koesoema, den raden aria Pringalaya en verdere hofgrooten zeer vriendelijk werden ontvangen en naar den soesoehoenan gebracht, die hen zeer minzaam verwelkomde en staande den brief van commissarissen in ontvangst nam.

De vorst betuigde zich zeer verheugd over hun komst, waardoor alle kwade praatjes, die van meer kanten waren uitgestrooid als zoude de Compagnie niets meer met den sultan te doen willen hebben, een einde zouden nemen en hij beloofde dadelijk maatregelen te zullen nemen om de Chineezen en alle rebelleerende Javanen in zijn gebied te verdelgen.

Daartoe zond hij op 21 Maart 1742 onder aanvoering van aria Pringalaya een leger naar Grobogan en den daaropvolgenden dag eveneens eene gewapende afdeeling onder den rijksbestierder Nata Koesoema naar Demak, om den vijand aldaar op te zoeken en zoo mogelijk te vernietigen.

Zeer belangstellend vroeg hij naar de gesteldheid van den troep die te Kartasoera in bezetting had gelegen, waarna de vorst aeen magnifique tafel met hollandse speijse deet toeregten *.

Uit de verschillende brieven door deze commissieleden aan hunne lastgevers te Semarang toegezonden, leeren we den ongelukkigen toestand aan het Kartasoerasche hof kennen. Van alle kanten omringd door vijanden, van wie de Madoereezen het meest gevreesd werden, met onbetrouwbare raadslieden om zich heen, met een bondgenoot, de Compagnie, die niet bij machte was den toestand volkomen te beheerschen, bovendien het geheele hof wantrouwde, doch uit eigen belang de vriendschap onderhield, zien we den vorst zich vastklampen aan Van Hohendorff, wiens raad bij elke gebeurtenis werd ingewonnen en die op elk uur van den dag, ook wel 's nachts, toegang tot hem had.

Werkelijk vertrokken niet alleen op de vastgestelde datums 
de aangewezen legers naar de hun aangewezen punten, maar ook andere plaatsen waar zich Chineezen en rebellen ophielden, werden door afdeelingen gewapende Javanen bezet.

Zijne Majesteit nu ook den indruk willende kennen die al deze maatregelen op van Van Hohendorff hadden gemaakt, liet dezen bij zich ontbieden en ondervroeg hem op de volgende punten: "(nadat bevorens de om sig sittende wagt van mijden ende bij sig hebbende tommongongs hadden laten vertrecken), of de gemaakte schikkingen betreffende het verdelgen der rebellen de goedkeuring van commissarissen te Semarang zouden wegdragen, waarop Van Hohendorff antwoordde, dat daaraan niet getwijfeld behoefde te worden, mits de uitvoering zou geschieden overeenkomstig de bevelen van den vorst.

Verder zou hij gaarne weten of de Gouverneur Generaal te Batavia verstoord op hem was, dat hij toch niet de minste schuld had aan alle onheilen van den laatsten tijd waarbij hij *(seggende dit met de traanen in d'oogen)» betuigde hoezeer het hem leed deed dat zulks was voorgevallen.

Voorts verzocht hij, dat door het kleine detachement Europeanen goede wacht bij hem zoude gehouden worden; tot hun komst had de ratoe elke nacht bij den vorst gewaakt en zou hij gaarne weder een Europeesch tamboer in zijne omgeving hebben opdat de Javanen uit diens getrommel konden bespeuren dat er weer Hollanders in den kraton waren.

Hoewel de onbeduidende 33-jarige vorst te goeder trouw was bij het uitvaardigen van alle orders die hem door Van Hohendorff in zijn eigen belang en dat van de Compagnie werden ingegeven, de uitvoering berustte in zulke zwakke en onbetrouwbare handen, dat niet alleen het beoogde doel niet werd bereikt, maar zijn val er integendeel door werd verhaast.

Blijkbaar was hij zelf overtuigd, dat zijn troepen, hoewel sterk in aantal, niet tegen den vijand waren opgewassen; of hij nu eens 1000 Mexicaansche dollars, dan weer het dubbele aantal uitloofde aan hen, "die in de attacque» het dapperst waren geweest, en de Javaansche veldoverste Gondo Salie, die met zijn leger naar Kartasoera was gevlucht, "tot exempel» met het kapmes het hoofd afkapte, indien de Compagnie niet meer daadwerkelijk medehielp, wanhoopte hij aan den goeden uitslag.

En daar was reden toe. 
Aria Pringalaya, de minst onbetrouwbare minister van den vorst, leed bij Grobogan een geduchte nederlaag tegen den vijand bestaande uit Chineezen, Javanen en Boegineezen onder aanvoering van Tamby, het gewezen hoofd der Arabieren op Joana, zoodat zijn volk niet mieer tot een veldslag te bewegen was. De bekommering van den soesoehoenan, dat de vijand zijn hofstad mocht aanvallen, terwijl die geheel van troepen ontbloot was, werd zoo groot, dat hij nogmaals dringend aan commissarissen te Semarang verzocht, hem wel met 's Compagnies macht te willen bijstaan.

Ook Van Hohendorff was van oordeel dat de vorst geholpen moest worden, en in strijd met den last van hunne Meesters te Batavia, ${ }^{1}$ stemden commissarissen den $17^{\text {en }}$ Mei 1742 toe, een voldoende macht naar Kartasoera te zenden, onder beding dat 4 aanzienlijke personen, n.l. de zoon van den keizer, kroonprins pangeran adipati Anom, 's keizers broeder pangeran ngabehi Loering Passir, benevens de oudste zonen van den rijksbestierder en van den raden aria Pringalaya als gijzelaars naar Semarang zouden worden gezonden "omdat het geheugen van het voorgevallene voorleden jaar en d'slegte behandeling door d'onsen aan sijn Eijgen Hof geleden al te versch was om op enkele beloften tewerk te gaan en wij nooyt tot Eenig besluijt van hulp aan sijn maj $^{t}$ zouden kunnen treeden dan op nadre versekeringe zijnentwege».

De soesoehoenan wilde hieraan gaarne voldoen, maar verzocht slechts zijn zoon, die nog jong en nimmer buiten het hof was geweest, te mogen vervangen door zijne moeder ratoe Amangkoerat en ngabehi Loering Passir, die aan een oude kwaal leed, en meestal ziekelijk was, door zijn broeder Boeminata.

$\mathrm{Na}$ eenige tegenwerpingen werd eindelijk op 2 Juni 1742 vastgesteld dat de kroonprins pangeran adipati Anom, de ratoe Amangkoerat en de oudste zoons van Nata Koesoema en aria Pringalaya als gijzelaars voor de Compagnie naar Semarang zouden vertrekken.

De vijand had echter ook niet stil gezeten. Met leede oogen had de tegenpartij de nauwere verbinding van het hof te Kartasoera met de Compagnie bespeurd en er was voor haar alles aan gelegen aan dat verbond hinderpalen in den weg te leggen. Van

\footnotetext{
1 Schrijven van 31 Maart 1742 van de Hooge Regeering te Batavia aan Commissarissen te Semarang.
} 
dezen vorst was voor hen weinig heil meer te verwachten; daarom verklaarden $z i j$ hem van den troon vervallen en riepen zij mas Grendie, een kleinzoon van,den op 17 September 1708 naar Ceylon verbannen adipati Anom alias soenan Mos, als tegenkeizer uit. Verder mochten de gijzelaars Semarang niet bereiken, daar alsdan de daadwerkelijke hulp van de Compagnie niet kon uitblijven en hierin vonden zij steun bij den verraderlijken rijksbestierder Nata Koesoema, die zooals we gezien hebben door den vorst met eene Javaansche legermacht naar Demak was gezonden, om de vijandelijke elementen aldaar aan te grijpen. Hij zond aan de vijandelijke Chineezen bericht op welk tijdstip de gijzelaars van Kartasoera zouden vertrekken omdat hij ongenegen zoude zijn, « zijn zoon mede als een geijselaar bij ons in versekering te stellen»; volgens Van Hohendorff om een gewenscht einde en den vrede te dwarsboomen. De vijand zond daarop ijlings een gedeelte zijner legermacht af om de wegen naar Kartasoera nabij Salatiga te bezetten en zoodoende het afreizen der gijzelaars te verhinderen, hetgeen door het werkeloos blijven van Nata Koesoema's leger ongehinderd kon geschieden.

Đe lankmoedigheid van commissarissen nam door deze gebeurtenis een einde. De rijksbestierder werd onder een voorwendsel naar de loge te Semarang opgeroepen en aldaar gearresteerd, toen bijna op hetzelfde oogenblik een brief van Van Hohendorff van den $13^{\text {en }}$ Juni 1742 aldaar werd ontvangen, waarin deze mededeelde dat Zijne Majesteit zeer neerslachtig was gestemd, omdat door de onveiligheid der wegen de gijzelaars niet konden worden afgezonden "hoewel die neerslagtigheijd en uijtterste droefenis was verminderd door de genereuse aanbieding van adsistentie door de Compagnie».

De vorst had verklaard in bijzijn van andere hofgrooten en zijne moeder dat het nu klaar en duidelijk was, dat hij door raden adipati Nata Koesoema op een "eerloose manier om den thuijn werd geleijd, , daar hij ongehinderd de rebelleerende Chineezen had laten doorgaan en de Kartasoerasche wegen had laten bezetten, waardoor de hoofdplaats, die nagenoeg zonder troepen was, in het uiterste gevaar verkeerde.

Hij verzocht daarom aan commissarissen een middel te beramen om hem van "dien sinisteren en onrustigen staatsman te verlossen waarop hij gaarne met de Commissarissen wilde besoigneeren, 
opdat dit op de secuurste wijze mag overlegd worden».'

Nog een brief van den $19^{\text {en }}$ Juni, werd uit Kartasoera ontvangen waarin de "pure onmogelijkheid " geconstateerd werd om de gijzelaars af te zenden; daarmede eindigde de briefwisseling uit de hofstad van Van Hohendorff met commissarissen. Wel werden ook later nog brieven afgezonden, maar deze bereikten Semarang niet daar zij door den vijand onderschept werden.

De Chineezen kwamen hoe langer hoe dichter bij de hofstad en daarmede naderde ook rasch het noodlot van den vorst.

De Javaansche troepen boden nog een zwakken tegenstand, doch in den namiddag van den $30^{\text {en }}$ Juni kwam de vijand van alle kanten den kraton binnen en konden den vorst met eenige naaste familieleden, benevens de bij hem zijnde Europeanen slechts door eene snelle vlucht hun leven redden. (Bijlage II).

Tot den $11^{\text {en }}$ Augustus 1742 bleven Van Hohendorff en de zijnen bij den vorst, die zich toen te Panaraga bevond.

1. De regeering te Batavia keurde deze daad goed en werd bij Resolutie van G.G. en Raden van Indië, dd. 3 Juli 1742 bepaald, dat de rijksbestierder in goede verzekering naar Batavia moest overgebracht worden doch Van Hohendorff moest een eigenhandig schrijven van den keizer verlangen, dat een verzoek behelsde om zijn eersten minister te willen arresteeren en van dezen maatregel aan de gezamenlijke regenten kennis doen geven.

Door den loop der omstandigheden, namenlijk de vlucht van den soesoe. hoenan, werd de overbrenging naar Batavia vertraagd, daar commissarissen oordeelden dat zijn tegenwoordigheid op Java in dien tijd nog van nut kon zijn.

In September daarop had het vertrek naar Batavia plaats onder geleide van den inmiddels teruggekeerden vaandrig Hogewits, die, als belooning voor zijne in den laatsten tijd bewezen buitengewone diensten, den 25 September 1742 tot luitenant werd bevorderd.

6 Nov. 1742 diende de rijksbestierder een verantwoording in, waarbij hij zijn onschuld betuigde aan den opstand van Java en mededeelde wat in dien tijd was voorgevallen ook betreffende het gedrag van den zwervenden keizer.

De commissarissen te Semarang om inlichtingen daaromtrent verzocht, betuigden dat daaraan nog niet kon worden voldaan omdat het hun onmogelijk toescheen om in dien verwarden tijd achter de waarheid te komen en het houden van een onderzoek in het geheel niet geraden was.

Dat onderzoek bleef achterwege en werd de rijksbestierder bij resolutie van 23 Juni 1744 "sonder verder in de zaak te roeren" naar Ceylon verbannen "tot loon van alle departen die hij ons in den Javasen oorlog heeft gespeelt"; bij het bepaalde van de resolutie van den $15^{\text {en }}$ September d.a.v. "gevolgd van wijff en kinders, die men met een soet leijntje herwaarts hadde gelokt, omdat die vrouw te veel crediet hadde an het Hoff om geen quaad te brouwen en te veel appuy door haren vader den Paccalongangs regent, om haar verblijff op Java niet min of meer te apprehendeeren." 
$\mathrm{Z}_{\mathrm{ij}}$ vertrokken daarop naar Soerabaya, alwaar $\mathrm{zij}$ den $17^{\mathrm{en}}$ aankwamen, scheepten zich den volgenden dag in en bereikten den $22^{\text {en }}$ Semarang, alwaar Van Hohendorff den brief van den soesoehoenan aan commissarissen overhandigde, die het voor de Compagnie zoo belangrijke bericht behelsde dat de vorst genegen was met de Compagnie een contract te sluiten, zooals deze hem zou wenschen voor te leggen, indien hij slechts door haar uit den nood werd gered. ${ }^{1}$

Ongeveer zes maanden zwierf de vorst door zijn gebied rond. Zijn doodsvijand, de prins van Madoera, had voor de Compagnie de kastanjes uit het vuur gehaald en in 't laatst van November 1742 toen commissarissen volgens hun schrijven van 20 Juni 1743 aan de Indische Regeering "door den swaaren geduurende dien maand gevallen regen van dien optogt (naar Kartasoera) hadden moeten affsien, » dien tijd waargenomen om een gedeelte zijner macht te laten oprukken naar de Hofplaats en den kraton op

$1 \mathrm{Na}$ den Chineesch-Javaanschen oorlog werden de brieven voor de Hooge Regeering ook over den landweg van Semarang naar Batavia gezonden, vooral in den westmoesson, als de gemeenschap ter zee niet was verzekerd.

Van Hohendorff, die na de terugroeping en veroordeeling van Elzo Sterrenberg in 1747 oppergezaghebber, en bij de verandering van Java's oostkust in een gouvernement, op 24 Februari 1748, gouverneur en directeur aldaar was geworden, begaf zich op het bericht van de ongeneeselijke ziekte van den soesoehoenan den $11^{\text {den }}$ December 1749 met spoed naar Soerakarta, de nieuwe residentie van den vorst.

Deze overleed den $20^{\text {en }}$ December, en den $24^{\text {en }}$ d.a.v. kwamen de brieven van den Gouverneur voor de Regeering te Batavia, betrekkelijk dit bericht en de verrichtingen van Van Hohendorff voor en na den dood van den sultan, te Semarang aan.

In 's.Comps. loge aldaar werd onmiddellijk de volgende resolutie genomen:

„Heeden in de nagt tusschen gisteren en van daagh van onse gebieder te dese custe in closa missive van Uw hoogEdele HoogAgtbaren welkens persanten en denkelijke afabelen inhoud ons momentlijk heeft doen vergaderen en resolveeren die opstonds over den landweg addresse te verleenen sijnde den Zergeant Rijke (brenger deses) wel Ernstig aangerecommandeert onder belooning d'uijterste spoed te maken die aangenomen heeft in drie daagen met Gods hulp costij te sullen bereijden, waarmeede wij met de uijterste Eerbied ons onderschrijven....."

Uit de geheime resolutie van 29 December 1749 van G.G. en Raden van Indië vernemen wij dat de „expresse courier" den $28^{\text {en }}$ December te Batavia was aangekomen, dus aannemende, dat hij nog den $24^{\text {en }}$ van Semarang was vertrokken, had hij het ongeveer $450 \mathrm{~K}$.M. lange traject via Indramajoe, in hoogstens vier etmalen afgelegd. De wegen en niet overbrugde rivieren van dien tijd in aanmerking genomen, dus een belangrijke prestatie. 
de Chineezen en de oproerige Javanen te heroveren, echter niet uit genegenheid voor de Hollanders doch uit haat tegen den Javaanschen vorst en met de bedoeling, die hoofdplaats nimmermeer onder diens gezag te brengen. ${ }^{1}$

Kort daarna, in het begin van December, kwam ook de soesoehoenan van Panaraga, via Madioen en Jagaraga nabij zijn residentie aan doch geenszins tot genoegen van de Madoereesche legerhoofden, die hem geen toegang tot zijn Hofplaats verleenden, maar eerst de orders van hun meester wilden afwachten.

Pangeran Tjakraningrat liet zich overreden de residentieplaats voor de Compagnie in te ruimen, 't geen den $21^{\text {en }}$ December geschiedde, nadat daags te voren onze troepen onder den commandeur Steinmetz Kartasoera waren binnengerukt.

Op denzelfden dag dat de Madoereezen aftrokken, werd de soesoehoenan, die zich in de onmiddellijke nabijheid bevond, door daartoe gemachtigden van de Compagnie binnen den dalem van zijn Hofplaats geleid.

Uit den brief door Steinmetz hierover den 24 December 1742 aan de Regeering te Batavia medegedeeld, zien we op welk eene geheel andere wijze de vluchteling zijn residentie weer binnen trad, dan hij haar ongeveer een half jaar te voren had verlaten.

a bij zijn Hoogh ${ }^{\text {ts }}$ aankomst liet ik door $10 \mathrm{Comp}^{\text {en }}$ een dubbelde ranquet maken waardoor die Majesteyd tot op de helft van de passeebaan gepasseert zijnde van het paard steeg en ik zijn Hoogheyd ontfing, leyde hem vervolgens op sijne ordinaire sitplaats (daar hij voor desen bij het Tournooyen gewoon was te sitten) alwaar hij de complimenten van alle present zijnde ministers Europeese en Inlandse officieren, alsmede. nog eenige agtergebleevenen madoereesen hoofden ontfing, hier een half uur met het drinken van een kopje thee en voorn. ceremonien

1 In zijn Geschiedenis der Nederlanders op Java deelt Van Deventer (II blz. 122, noot 1) hieromtrent mede:

${ }_{n}$ De commissaris Verijsel c. s. verklaren geen de minste zwarigheid te maken om op te trekken naar de keizerlijke hofstad, doch zij zijn verlegen om orders nopens den gedetroneerden keizer, schreven G.G. en Raden zelve aan de Bewindh. (de Jonge IX blz. 419, 20.)

Het is derhalve onjuist wat de heer De Jonge op bl. LXXXVI beweert: "dat men te Semarang weifelde en talmde"."

Uit het hierboven aangehaalde blijkt dus, dat de bewering van De Jonge juist is, want hetgeen 's-Compagnies troepen nalieten, zoogenaamd om den regenmoesson, werd tezelfder tijd wèl door het Madoereesche leger verricht. 
doorgebragt hebbende versogt den vorst dat ik hem dog bij sijn moeder de ratoe ageng amancoerat wilde brengen, die hij haar in het oog krijgende van mij aflopende om den hals vloog en een geruyme tijd onder het storten van bittere tranen op de grond leggende doorbragt ${ }^{1}$ totdat ik zijn Hoogheyd en desselvs vrouw moeder van malkanderen haalde en haar uyt name van d'E Comp. filiciteerde met 's-vorsten herstelling op den Javaschen troon, waarvoor Zijne Hoogh. mij zeer bedankte en zijde dientwegen aan $U$ HoogEdele grootagtb. mede zijn verpligting te zullen betuygen, des middags versogt zijn Majesteit mij met hem het middagmaal te houden en dat ik mijn hollandse speijse soude laten binnen brengen ook dat sijne medevlugtelingen te weeten den Capitain Hohendorff, den luytenant Hogewits en trains Secrets Toutlemonde mede bij hem mogten eten .......,

Nu moest echter de Compagnie nog schadeloos gesteld worden niet alleen voor haar goeden naam, die door de schending der tractaten zoo zeer had geleden, maar ook voor de vele opofferingen die zij zich ook nu weer, zoogenaamd ter wille van het huis Amankoerat, had getroost; daarom werd de soesoehoenan verzocht, naar Semarang te komen om met commissarissen het noodige te bespreken, met het oog op het sluiten van een nieuw contract.

Maar 's Compagnies loges te Semarang en Soerabaya, zoo dicht aan zee gelegen, waren een schrikbeeld voor den vorst. Evenmin als van Hohendorff er hem toe had kunnen brengen tijdens zijn vlucht, zijn heil aldaar te zoeken, voelde hij thans lust om derwaarts te gaan, waarom hij verzocht slechts zijne gemachtigden te mogen zenden.

1 De groote vereering die den vorst jegens zijne moeder aan den dag legde, blijkt ook uit het volgende:

Bij de reis van den Gouverneur-Generaal van Imhoff over Java in Mei en Juni $1746 \mathrm{kwam}$ de soesơhoenan te Semarang bij dezen zijne opwachting maken.

Hoe ontdaan de sultan ook was door de buitengewone ontmoeting, verzocht hij toch bij de receptie, die in 's-Compagnie's loge te Semarang plaats vond, dat ook zijne moeder, de ratoe, kinderen en nabijstaanden mochten binnenkomen ${ }_{n}$ en voor de eerst gem. zelfs op staande wanneer zij binnenquam...."

(Zie: Bijdragen tot de Taal-, Land- en Volkenkunde van Ned.-Indië I, 1853, blz. 389). 
Blijkbaar was 's vorsten geweten niet àl te zuiver en bedacht hij, dat op een vertrek daarheen, wel eens geen terugkomst kon volgen.

In de volgende woorden verontschuldigde hij zich daarover:

"maar grootvader, ik twijffele niet off het is Uw hoog Edelheedens bekent dat ik thans 6 maanden van Cartasoera ben weg geweest en mij in 't bosch heb opgehouden waardoor zeer vermoeijt en ook van alles ontrieft ben en met fatsoen niet kan te voorschijn komen ofte in statie sooals een keijser behoort en niets bij mij hebbe als gemene volkeren en alles wat aan keijserrijk behoort heeft is absent geraakt, soo weet ik ook niet op wat wijse ik op Samarang soude kunnen komen dewijl mijn gezag nog kleijn is». ${ }^{1}$

Waarschijnlijk is den vorst nimmer ter oore gekomen de inhoud van de geheime order, dato 29 Juli $1743^{2}$ van de Indische Regeering aan den kapitein van Hohendorff, die intusschen op speciaal verzoek van den soesoehoenan weder als minister van de Compagnie en hoofd der troepen te Kartasoera was opgetreden, anders zou hij bespeurd hebben, dat hij zich niet ten onrechte bevreesd had gemaakt over het lot dat hem boven het hoofd zweefde.

Bij die order, die door Van Hohendorff den $12^{\text {en }}$ Augustus 1743 ongeopend aan de Regeering te Batavia werd teruggezonden wijl het daarin uitgedrukte bevel niet behoefde uitgevoerd te worden, was aan dien officier opgedragen den soesoehoenan met zijn zoon, den kroonprins, onverhoeds op te lichten en naar Semarang te zenden, indien hij niet zou willen voldoen aan den eisch van de Hooge Regeering, of liever speciaal dien van den Gouverneur Generaal van Imhoff, uitgedrukt in een geheimen brief van dienzelfden datum om de beide hoofdaanleggers van het gebeurde in den kraton op 20 Juli 1741 onmiddellijk aan de Compagnie uit te leveren.

Men had daarbij de voorzorg genomen eenige schepen naar Semarang te zenden en onder voorwendsel dat "de marinen * (manschappen van de oorlogsschepen) de troepen te Kartasoera moesten aflossen een detachement van 100 Europeanen daartoe aan wal gezet.

1 Schrijven van den soesoehoenan aan de Regeering te Batavia, dato 17 Jan. 1743.

2 Zie De Jonge Opkomst, deel IX, blz. 433, noot. 
In 4 groepen zouden die militairen naar de Hofplaats afmarcheeren, elke afdeeling onder een vertrouwd officier en op zoodanige tijdstippen, dat wanneer het eerste deel Bojolali had bereikt het $2^{e}$ en $3^{e}$ respectievelijk te Salatiga en Oenarang zouden zijn aangekomen en het $4^{\mathrm{e}}$ alsdan tot vertrek gereed stond om op marsch te gaan tot Banjoedena, zoodat zoolang de zaak gaande was, militairen op het traject Semarang-Kartasoera aanwezig zouden zijn. Bij elke groep waren zes à acht gezadelde paarden, zoo het heette voor de officieren en onderofficieren of voor hen, die den marsch niet konden meemaken, maar in werkelijkheid tot verwisseling der paarden van de arrestanten en het escorte, want de opdracht moest zoo snel uitgevoerd worden dat wanneer het bericht van de gevangenneming van den soesoehoenan Semarang bereikte, ook de gearresteerden daar reeds zouden zijn aangekomen. Met het afzenden van den geheimen brief aan den kapitein van Hohendorff zou tegelijkertijd de eerste afdeeling militairen van Semarang vertrekken. Deze maatregelen bleken gelukkig niet noodig te zijn geweest.

De vorst toonde zich onmiddellijk bereid niet alleen den opperpriester said Aloewi uit te leveren (radja Nitie, de andere verlangde aanstoker, was inmiddels overleden) maar ook nog een anderen hoofdschuldige aan die misdaad, hadji Mataram, daar deze beide personen met den rijksbestierder volgens confessie van den overleden toemenggoeng radja Nitie het complot tegen de Nederlanders beraamd hadden.

Van Hohendorff heeft dus de voor hem zeker pijnlijke opdracht niet behoeven uit te voeren, al was hem in de genoemde geheime order in 't vooruitzicht gesteld "Recompense na merites, zoo deezen onzen Last naar de intentie gelukkig werd volbragt». ${ }^{1}$

Het getuigde ook van weinig fiijngevoeligheid van den Gouverneur Generaal van Imhoff, dezen officier, die zooveel lief en leed, maar vooral het laatste, met den vorst had gedeeld en die in zijne den $27^{\text {en }}$ Augustus 1743 aan de Regeering in te dienen "consideratien en remarques» (Bijlage III) zou toonen den vorst te beschouwen als iemand die de Compagnie oprecht gezind was, voor deze netelige zaak uit te kiezen.

1 Bij resolutie van 26 Nov. 1743 werd Van Hohendorff bevorderd tot majoor, omdat hij "sig in alle dese omstandigheden seer wel gecomporteerd heeft". 
Er werd bij den soesoehnenan niet verder op aangedrongen tot het sluiten van een contract naar Semarang te komen; daartoe zouden commissarissen naar Kartasoera vertrekken, waarbij terwille van het prestige genoegen werd genomen met de toezegging dat de vorst de gemachtigden van de Regeering tot Madjasanga, ongeveer $2 \frac{1}{2}$ uur van de Hofplaats, zou tegemoet rijden en «te zijner rechterzijde zoo te paard als aan tafel sittende te plaatsen».

Het verhaal van deze episode uit de Javaansche geschiedenis, eigenlijk een fragment uit den Javaansch-Chineeschen oorlog, mag niet besloten worden zonder een woord van hulde aan die enkele compagniesdienaren die door hun kalm beleid en onverschrokken gedrag het Nederlandsch gezag gered hebben in tijden, dat de Indische Regeering, den $5^{\text {en }}$ December 1742 , aan het opperbestuur omtrent Java schreef als "het comptoir dat ons successive een onbeschrijffelijke moeijte en verdriet veroorzaakte ja genoegzaam bij continuatie gehouden heeft in een bijna radeloose bekommering*. 


\section{BEANTWOORD}

door den E Heer hugo Verijsel Commissaris over de zaken op en langs Javas noordoostcust benevens Joan herman theling tweede in de opgem. commissie navolgens Uw hoog Edele grootagtb. gevenereerde ordre vervat bij aparte letteren van den 30 december A. ${ }^{\circ}$. 1741.

\section{INSTRUCTIE}

voor den E Hugo Verijsel commissaris over de zaken op en langs Javas noordooscust om te dienen en tot narigt en opvolginge zoo omtrend het handelen en tracteeren van vreede met den soesoehoenang als het renoveeren der voorigen contracten, privilegien en octroijen successive aan d'E Compagnie verleent tot het ten eijnde brengen van den presenten oorlogh zal mogen en moeten , werkstellig gemaakt werden. ${ }^{1}$

\section{PRELIMINAIRE POINCTEN.}

De reedenen waarom d'amnestie ten aanzien der chineesen niet is werkstelligh gemaakt in voegen als $\mathrm{U}$ hoog Ed. grootagtb. ons hebben gelieven aan te schrijven bij missive van den 14 en 28 november zullen U hoog Edelheid's vervat vinden bij onse submisse gem. en aparte letteren van den 30 november en 12 december waar en tegen Uw hoog Edele groot agtb. bij onse brieven van den 24 decemb. 1741 en 20 Jann. deses Jaars zal consteeren, dat wij ter voldoeninge der consideratien, die Uw hoog Edelheedens ons hebben gelieven te supediteeren bij meer gem. letteren van den 28 november wij eene andere weg hebben ingeslagen op aanradinge en rijpe overwegingh met den Chinee-
Dat den vorst zigh zal moeten verbinden om alle zodanige Chineesen die van d'amnestie welkers publicatie UE bereedts is aanbevoolen bij brieven van den 14 en 28 novemb. pass $^{\circ}$. niet mogten hebben geprofiteerd navolgens het voorgestelde bij het 5 en 11 art. der contracten op den 24 Septemb. 1646 en 28 febr. 1677 met zijn hoogheijts antecesseurs gesloten, niet alleen aan te zien voor algemeene vijanden maar ook alle dezelve, in soo verre die op de Javaschen bodem mogten te vinden zijn zonder uijtstel te laten verdelgen, uijtroeijen en doodslaan zonder Eenige van dien in het leven te mogen laten op pretext dat deselve het mahometaansche

1 Dit handschrift is woordelijk gevolgd, ofschoon de copiïst dikwijls zinstorende schrijffouten heeft gemaakt.

Dl. 74 
sen luijten ${ }^{t}$ quee Jonko, die ons veel honorable voor d'E. comp. is te vooren gecomen en aangesien de staat waarin de chineesen zigh thans bevinden en waarvan wij het ecces dagelijks te gemoet zien gelijk $\mathrm{U}$ hoog Edelen groot Agtb. wijds. ter voldoening van dit poinct off de bereedwillige van den keijser om de chineesen te verdelgen zal te vooren komen uijt desselfs schrijven alhier ontfangen op den 6. 12 : en 23 Decemb. mitsgad. 9 Jann. 1742 en dat dit articul ten deele zijn beslag heefft erlangt en door Radeen adepatty en andere Regenten werkstellig gemaakt zullen $U$ hoogEdele groot agtb. des gelustende kunnen b'oogen uijt onse aparte letteren en dies bijlagen de datis 24 en 28 decemb. die der Japarasche en Tagalse be-

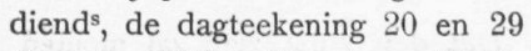
decemb. 1741 mitsgaders uijt de translaat Javaansche brieft van den eersten strand gouverneur adepattij Djeja ningrat tot Pacalangan op den 3 dezes ontfangen des wij onder gunstige welduijding van $\mathrm{U}$ hoog Edelheeds. sustineeren dat met de verdeeltheijd, die wij tusschen de Javanen en Chineesen bewerkt hebben; waardoor veele den hals gebrooken en andere op de vlugt gedreven zijn - dit articul genoegsaam volbragt en geEffectueerd is en over sulx niet verder ter uijtvoeringe kan gebragt werden voor en aleer een scheijding komt tusschen de goede en quaadwillige Chineesen, waartoe wij de vereijste maatregels hebben genomen blijkens drie Chineesen copia translaten de datis 16 en 28 decemb. 1741 en 10 Jann; die den meerm. gelooff aangenoomen hadden of genegen en gereed waren hetzelve aan te nemen en ten eijnde dit gespuijs in het geheel van die kuste magh afgeweerd en de ruste hierdoor des te meer verzeekert worden. 
que Janko met drie welbekende chineesen, die alhier in detentie hebben gezeeten heeft verzonden, hiertoe schijnt den rijxbestierder nog een nadere weg te banen bij zijn brieff den 14 decemb. alhier ontffangen waarbij hij mentie maakt de woedende chineesen, die dan niet declareeren of geneegen zijn om pardon te verzoeken van d'E Comp. of den soesoehoenang te zullen attacqueeren na vermogen en hun te vernielen ten welken eijnde hij de chineesen intussen aanlokte in der minne om hun te laten of zij mogelijk genegen waren zich in voegen als voren 't onderwerpen waarop wij dien doorsleepen staatsman hebben gedient dat de Chineesen Comps. onderdanen waren blijkens de contracten en derhalven zigh aan haar moesten adresseeren. alzoo het pardon van den keijser verleent tot geen voldoene satisfactie voor d'E Comp. konde strecken des wij niet twijffelen of door het Cartasoerasche hoff zal hierop nader Reftexie geslagen en ons verder oogmerk gefaciliteerd worden.

Bij onse missiven aan den keijser geright de datis 7 en 24 decemb. 1741 mitsgads. 16 Jann. 1742 soo meede bij die aan den rijxbestierder van den 9 en 15 dezer zal $U$ hoog Edele groot agtb. te voren komen dat wij bij den vorst g'insteert hebben nopens het nevenstaande articul en hij bij desselvs rescriptie alhier op den 23 december ontfangen niet ongenegen is daaraan te voldoen alhoewel hij bij een brieff van den 5 Jann. en alhier op den 9: daaraan

\section{Articul.}

Van den soesoehoenang te eijsschen de restitutie van alle de militairen en verdere dienaren van d'Ed comp. met en benevens derzelver vrouwen en kinderen dewelke haar met den aanvang van den Jongsten oorlogh in de Cartasourasche vesting en elders mogten hebben bevonden en alsnog in levenden lijve mitsgaders onder zijn $\mathrm{Hoogh}^{\text {ts. }}$ maght te vinden zijn schoon dat deselve ofte Eenige van haar ongenegen moghten bevonden worden om tot 
ontfangen verzoekt dat de bezettelingen tot Cartasoera mogen blijven waght houden na het voorbeeld zijner voorvaders, waarvan twee Reedenen te geven zijn namentl. dat den vorst mogelijk bedught is, zijlieden veele onstigtelijke zaken als de besnijdenis de behandeling tegen den commandt. van Velsen en wes meer aan den dag zullen brengen dan wel dat sommige van het gemeen bevreest zyn zijlieden gestraft zullen werden door dien uijt eenige relasen en andere omstandigheden genoegsaam af te leijden is dat ze nalatig zijn geweest in de vereijschte getrouwheid aan den meerm. commandant en andere officieren des zij den keijser zullen versogt hebben, aldaar te moge verblijven, waarop wij den vorst hebben g'antwoord in voegen als $\mathrm{U}$ hoog Edele agtb. zullen vervat vinden bij letteren van den 10 Jann. dogh in desen men gelooff mag slaan aan diverse mondelinge relasen, die door den van Cartasoera ontvlughten frederik Walraad geconfirmeerd werden zou den vorst kleederen voor officieren en zoldaten laten maken, waarna Eenelijk gewagt wierd overzulx wij vernemen, dat hier verder niet aangedaan kan werden dan de Belofften van den keijzer of te waghten en in tusschen blijven persisteeren bij de reeds gedane instantien.

Dat dit bereedts door ons is werkstellig gemaakt consteert bij onse brieven aan den keijzer gecarteerd de datis 23 en 26 novemb. mitsgads 7 decemb. zoo mede bij die aan den Radeen Adepattij van den 15,
d'E comp. weder over te komen waaraan geen het minste gehoor zal mogen verleend maar dezelve gerestitueerd moeten werden sonder daaromtrent eenigsints in gebreeken te blijven.

\section{Articul.}

Gelijk dan alsmede tot een waare blijk van genegenth ${ }^{t}$. en tot het cultiveeren van d'oude vrund en bondgenootschap tussen het mattaramse rijk en d'E comp. door den keijzer ten Eersten zal moeten 
23 en 28 novemb. dat den vorst en desselvs Eersten minister hierto 3 bereijd willig zeijn geweest zullen $\mathrm{U}$ hoog Edelh. vervat vinden bij desselvs missiven alhier op den 25 novem. 6 decemb. ontvangen, en dat dit articul sijn beslag heeft bekomen op Sourabaija en passourouang na, hebben wij d'Eer gehad U hoog Ed le $^{\text {groot agtb. te bedeelen }}$ bij onse onderdanige aparte letteren van den 24 decemb. soo als sulken mede te sien is bij missiven der Japarasche en tegalsche bedientens van den 14, 17 en 21 decemb. mitsgads. 19 en 29 deselven maants verder twijffelen wij niet off zullen ter Eerstegelegentheijd een gewenste tijding van Sourabaija bekomen ten minsten zo men gelooff mag slaan aan den inhoud van 's-keijzers brieff in dato 5 Jann.

Dat dit laatste preliminaire poinct niet is werkstellig gemaakt is gesteld, eensdeels omdat wij gesustineerd hebben dat de gecontracteerde leverantierijst en dies gestepuleerde penningen voor de bezettelingen sorteerde onder de formeele off essentieele vreedensarticulen als een zaak die van zelfs moet volbrengen ten anderen omdat $\mathrm{U}$ hoog Edele groot agtb. ons hebben gelieven te ordonneeren bij aparte missive van den 28 9ber, dat wij moeste zorg dragen ons niet verder ter zake ten principalen dienende in te wickelen als breets geschied was dewijl wij met Uhoog Edelheeds' gerespecteerden bevelen en goedvinden stonden voorzien te werden oversulks wij ons Comp. wegen niet hebben durven arder gesteld en daar van het Effect bezogt werden dat alle de in de wapenen getrocken Javaanen die sigh op tagal, sourabaija, passarouang, Japara en elders waar dezelve sigh ten oorlogh uitgerusten ook mogten bevonden weder affgedankt en een ider van zijne was (?) plaats gemitteerd werden mitsgaders dezelve daar benevens g'interdiceerdt het plegen van eenige vijandelijkheden tegen de volkeren van d'E comp.

\section{Articul.}

Dat aan d'E comp. door zeijn hoogheijts order almede zoo spoedig doenlijk zal moeten geschieden de leverantie van de gecontracteerde Rijst voor het Jaar 1741, dewelk zijn hooght. gehouden en verpligt is te leveren benevens de penningen en bij de contracten gestipuleerd en bedongen zoo in mindering van zijne agterstallen als ter betaling der Cartasoerase bebezettelingen, met dese reserve nog tans, dat ingevallen den vorst of de zeijnen mogten te kennen geven derzelver onvermogen tot het contribueeren der verschuldigde penningen, dat in zoo een gevalle UE zal moeten overtreeden, om in dies plaatse soo veel Rijst van haar te accepteeren als in mindering van 
uijtlaten eghter particulier en als uijt ons zelvs bewerkt het openen der Rivieren om dus den Aanbreng van Rijst voor contante betalen te faciliteeren sooals U hoog Edel groot agtb. zal vervat vinden bij onse letteren de datis 239 ber en 27 xber aan den Keijzer en Rijxbestierder ges $^{n}$ gelijk nader geconfirmeerdt is door den mondelijke belofften van den laastgenoemden bij onse onderdanige aparte missive van den 28 decemb. vermeld welke versoekt en verspreeking zekerlijk van Effect zoude zijn geweest indien de gure $\mathrm{w}^{\text {st }}$ mousson zedert eenige dagen niet sterk door gebrooken waar 't welk de inlandse piloten bevreest maakt zigh met hunne kleine vaartuijgen op zee te begeven. gedagte schuld mogte wesen te bekomen ten eijnde aldus door een of anderen weg de agterstallen van meerm. soesoehoenang in de palmen en maghtig te werden.

\section{PRINCIPALEN VREEDENS ARTICULEN.}

Dewijl dit een poinct is dat tot grondslag strekt van alle vreedenstractaten word dit als een zaak van zelve sprekende antwoord.
Eerstelijk dat $z i j n$ hooght in volle vigeur zal moeten laten en houden alle contracten die tussen zijn $\operatorname{hoogh}^{t}$ en desselvs voorsaaten ter eenre en de Comp. ter andere zijde zijn gemaakt en geslooten in zooverre die bij het te maken tractaat niet zullen werden gecontradiceert nevèns de verdere prevelegien en octroijen aan d'E Comp. successivelijk verleent.

\section{2.}

Tot de onaf hankelijkheijd van den prins van madura en zijne nakomelingen zal den keijzer mogelijk na onse gedagten wel te beweegen zijn vooral wanneer de doorgemelde prins g'invadeerde landen wederom aan den keijzer in vollen eijgendom wierden gerestitueerd des wij $\mathrm{Uw}$
En ten tweeden, dat den soesoehoenang van den prins van madura dewelke door de Comp. onder derzelver bescherming is genomen niets zal vermogen te Eijsschen of pretendeeren 't zij uijt hoofde van vassalage dan wel andersints maar dat zijn hooght voor hem en zijn 
hoog Edele groot agtb. verzoeken om met derzelver gerespecteerde ordres nopens dit poinct te mogen werden voorsien, dewijl wij hoe met deze landen zal werden gehandelt niets bij onse instructie vinden ter neder gesteld en het buijtendien een saak is van veele consideratie, die indertijd strijdigh zoude kunnen zijn met het interest der E Comp. dat een prins so onderneement als den madurees en zijnen zonen een vasten voet en Java had, waardoor ten alle tijde in staat zoude sijn met een formidable arme tot in het hart van 't Rijk in te rukken.

Deze zaak schoon op deselve volstrekt tot maintenue van 's comp. credit g'insteerd dient oordeelen wij van weijnige difficulteijt door den geduurende dezen oorlogh geenen voorbeelden van sodanige overkomst te vinden zijn geweest dan alleen den Ingabij Satja nagara volgens het schrijven der Japarase de dato 11 en 21 decemb. 1741 't welk nogtans meer uijt haat tegen den Regent adi pattij tsjitrasoema als wel uijt genegentheijd voor de E Comp. schijnt ontsprooten te sijn.

Dit artijkel schijnt in den Eersten opslag zeer heijlzaam voor d'E Comp. en het ware te wenschen dat derselver belangen door een welmenent rijksbestierder aan het hoff wierden behartigt ook dat bij verkiesing van zulks een staatsman den welmenenste wierde voorgedragen maar aan d'andere kant komen in dese volgende swarig- successeur, zoo voor het tegenwoordige als toekomende ter contrarie zal moeten beloven dien Prins als ten Eenemaal van hun afthankelijk met desselvs bezettingen en nakomelingen voortaan ongemoeijd te zullen laten en voor altoos van desselvs reght ten behoeve de Comp. te renunceeren zonder iets te Reserveeren direcd off indirecd.

3.

Ten derden zal zijn hooght ${ }^{t}$ bij het aan te gaan vreedenstractaat verzeekering moeten geeven en beloven dat denselven alle Javaanse hooffden, Regenten en anderen Javanen die haar onder 's Comp. protexie en bescherminge mogten hebben begeven of nog sullen bekomen te geven ter dier oorzaak niet sal molesteeren of lastig vallen.

4.

Ten vierden dat den soesoehoenang de aanstelling van den Rijxbestierder voortaan zal moeten doen met voorkennisse en volkomen toestemminge van d'E Comp. mitsgaders denselve niet uijt zijne waardigheijt en bedieninge mogen werden gedimoveerd dan met gelijke voorkennisse, approbatie en consent van de maatschappije. 
heeden te vooren, die wij de vryheijd neemen $U$ hoog Edele groot agtb. voor te dragen dat namentl. dus den keijzer te veel in zijne magt en vrije verkiesing zoude schijnen bepaalt te zijn in geen vertrouwen hebben in zijnen voornaamsten minister een raadsman of dat hem eenen gantschelijk tegen zijn zin zoude scheijnen opgedrongen te worden, ten anderen dat in het voordragen van zodanige een Regent veeltijds eenige dienaren der Comp. door baatsugt verleit dengeenen souden aanprijsen, die hun het meeste voordeel aanbood en dien zij dan ook in zijnen quade ondernemingen genegen zouden zijn te maintineeren, waarbij nog gevoegt kan worden de argwaan, die den presenten rijxbestierder uijt die articul zoude kunnen opvatten alsof hetselve op sijn perzoon betrekkelijk was buijten en behalven dat zoodanig een staatsman na genoegen der E. Comp. en niet met een na de zin des keijzers zijnde gevaar zoude lopen onder het een of ander present lightelijk door sijnen souverain verstoten dan wel door de zulke die gaarne in zijn plaats zouden willen succedeeren ten onregte beschuldigt te werden waarop wij dan U hoog Edele groot agtb. nadere consideratien en g'eerde beveelen sullen blijven affwagten.

5.

Deze pretentie so billijk sijnde dat den keijzer indien tot vreede genegen is niets tegen dezelve met reght kan inbrengen, blijftt de swarigh $^{t}$ alleen daarin dat dewijl de oorlogsonkosten en geledene
Eerste $\S$

ten vijfden dat ged. vorst almede zal moeten beloven en sigh verbinden om alle onkosten, schaden slegtingen ende vastatien de Comp. door de rebellie en den oorlogh 
schaden grote sommen gelds sullen Bedragen op zijn hooght bij inwilligen in staat wesen sal in contanten gelde te voldoen bij aldien daartoe onvermogende zigh verklaardt in hoedanige termijnen 't sij in contanten of het Equivalend van dien in Rijst en andere waren de selve sullen mogen gestipuleerd worden. Schoon dese pretentie al immer soo billijk is als de vorige kan men van deselve verwagting van voldoening niet hope want indien een of twee Regenten als de oorsaken dezer troublen konden werden aangemerkt souden onmogelijk niet veel swarigheijd sijn die in 's Comp. handen over te doen geven maar dewijle de keijzer in zijn brieven selfs genoegsaam schuld bekent en de Rijxbestierder niet min coupabel is ook niemant der regenten 't eenemaal onschuldigt kan gehouden worden sal het onmogelijk sijn op dit stuk te blijven staan en zij alle eene lijn trekkende zal het niet min onmogel. zijn het hooffd off den eersten autheur te ontdekken of behoorlijk ondersoek na denselven te doen des wij van gevoelen sijn dat d'E Comp. geen Regtmatige voldoening omtrent dit poinct kunnende Erlangen het best is daar van af te zien.

Dese zaak als onwedersprekelijk zijnde, zal den keijzer, niet af zijn konnen zigh dese kosten en vergoedinge te onderwerpen. dan wel te dier zake op eenige handerwijse gecauseert aan deselve in contanten gelden te restitueeren te vergoeden en te voldoen.

$\S 2$. Item alle degeene die oorsaak moghten wezen van de onmenschelijke behandelingen 's Comps bezettelingen tot Cartasoera aangedaan over te geven aan meergem. maatschappije ten eijnde daar mede gedaan en gelaten te werden en goed vinden sal.

Ten zesden den soesoehoenang daarenboven door belofte ook te verbinden om met den eersten de nodige materialen nevens de VerEijschte coelijs of Javaanen te beschikken tot den wederopbouw der Rembangsche vesting, item tot herstellinge en wederopbouwing van hetgeen so aan als omtrend de vesting tot Samarang, tagal, damak, 
Aangaande dit alsmede het volgende poinct is geene swarigheijd also den rijxbestierder en andere regenten het canon, mortieren en verdere geweeren op de Chineesen veroverd uijt eijgen liberatie ons alhier hebben toegesonden.
Maar aangaanden de neevenstaande pretentie hoe wenschel. ook deselve voor d'E Comp. mogte schijnen kunnen wij niet afsijn U hoog Edele groot agtb. voor te dragen 'tgeene wij nopens de uijtvinding van den Commissaris dubbeldekop in zijne brieff van 23 maart 1723 om tot voldoening der oorlogskosten de lembarawas en de samarangse sabandharij daarvoor te bedingen, bij apart schr. der hooge Indiase Regeering van den 7 meij daaraan volgende genoteerd vinden dat men dese propositie vrij Exarbitant vond ende besloten gerugten van sodanigh een petitie zulk een vreese in de Javaanen had gebragt, dat seedert aan het
Japara, Jawana, Sourabaya, en Passoerouwan als elders beschadigt mitsgads door brandstigtinge als $^{\mathrm{s}}$ andersints vernieldt en gedestrueert is geworden en zulx van steen en in zodanigen staat als waarinne de maatschappije deselve sal begeren gemaakt te hebben als ten kosten van zijn hoogheijd.

Ten zevende te contracteeren en bedingen de restitutie van al het canon en verdere ammunitien van oorlogh, hetgeene ten tijde Rembangh is overrompeld daarinne te vinden is geweest.

Ten agsten de overgave van al het canon, mortieren en ammunitie van oorlog hoedanig die ook genaamt zoude weesen dewelke in de fortres tot Cartasoera gevonden is nevens het Opper en onder geweer van het quarnisoen dat aldaar bescheijden is geweest.

Ten negende van zijn hooght onvermindert alle de bovenstaande articulen en poincten almede te bedingen den afstand en overgave in volle souverainiteijt en eijgendom van alle desselfvs stranden met hunnen aff hankelijkheden en de daaronder gehorende volkeren sonder eenige Reserve Evenals dat op den 58 ber $\mathrm{a}^{\circ} 1705$ bij het doenmalig gesloten contract op art. 4 ten aanzien van de landen van Sumanap en pamacassan is geschied, mits$\operatorname{gad}^{\text {s }}$ (desnoods) daarentegen tot een equivalent van voorsch. affstant een somma gelds namaten den keijzer sigh hiertoe genegen komt te tonen te detraheeren van de Downloaded from Brill.com๑4/26/2023 12:20: ๑4AM 
hoff van geen vernieuwing der contracten gesproken was, als sijnde deese deliquidiste en best Revenuen van den vorst, indien nu deese voorgem. twee poincten van sulk een vooruijtsigt zijn geweest, dat men daarvan ten eenemaal heeft afgezien, zal het ons bedunkens vrij meer in hebben den vorst tot den affistant van het beste gedeelte sijner Landen te beweegen.

Te meer wanneer men hier komt bij te voegen hetgeene ten dezen opsigte bij instructie van den Edele heer Raad Extraords en Commissaris frederik Julius Coijet vervat staat luijdende aldus;

Dog wij menen in het generaal dat men voor d'E Comp. van geen landen meer behoorde te spreeken om den Javaansen vorst geen indruk te geven tegen onse goede intentie alsof de neederlandsche maatschappije sijn Rijk soo gaande.weg sogt in te slicken en een weijnigh verder daarvan zal het best weesen niet alleen van voornoemde lembarawas maair ook van alle andere pretentien van die Natuur aff te sien, wanneer nu hierbij in aanmerking komt dat den vorst door het affstaan aller sijner stranden als binnen sijn land opgeslooten is beroofft van het grooste gedeelte sijner inkomsten; zijne onderdanen verstoken van hunne Rivieren en zeehavens genoodsaakt van hunne landvrugten alleen te bestaan en die tegen een geringe prijs te verkoopen is het niet te vermoeden dat den soesoehoenang eeniger wijse tot dese harde pretentie sal over te brengen zijn. pretentie die de d'E Comp. ten laste van sijn hoogh ${ }^{d}$ is hebbende. 
Maar het is ten hoogsten billijk dat bij aldien den keijzer tot den affstant sijner seestranden niet te beweegen sij en sigh almeede buijten staat verklaart tot de voldoening der gedane swaare kosten en sijner verdere aghter stallen dat men alsdan tot de volkomen voldoeninge toe sijn hoogh ${ }^{d}$ verpligt tot het veronderpanden zijner hiernevens gementioneerde landen en zeestranden gelijk zulx bij sijn hoogh ${ }^{t_{*}}$ voorsaten in diergelijke gevalle en door een formeelen acte van verbintenis tusschen den keijzer en den heer Raad ordinaris Cornelis Speelman op den 19 en 20 8ber 1677 :

Tot Japara gesloten geschied is wanneer almeede bij sulk eene gelegenth $^{\mathrm{d}} \mathrm{g}^{\prime}$ 'insteert soude konnen werden om in mindering van schuld de gronde en omleggende streeken van Japara den soesoehoenang in vollen eijgendom te bedingen; omtrend welke plaatsen om derselver aangelegenth ${ }^{\mathrm{d}}$ de hooge indiase regeering ook haare gedagten ter neder gesteld bij meer geciteerde instructie voor den heer raad Extra Ordon $^{s}$ Coyett inmiddens om gewigtigheijd deser poincten zullen wij de nadere gevenereerde ordres en consideratien Uwer hoog Edelegroot agtb. blijven affwaghten.

Onse remarques en swarigheijd op de vorige poincten UhoogEdel grootagtb. met schuldige Eerbied dogh openhertigh dus voorgedragen hebbende, willen wij hoopen en wenschen dat den Keijzer de Redelijke voorslagen hem door d'E in deesen gedaan niet sal van
En ten dien eijnde dogh den keijzer zigh hiertoe ten eenemaal ongenegen tonende waartoe eghter door UE alle mogel. devoiren sullen moeten int werk gesteld werden alsdan zijn hoogh ${ }^{d}$ bij faute van een prompte betaling voor het geheel debet en agterwesen nopens de oude en nieuwe schulden te laten onderpanden alle desselvs landen met haare ap- en dependentien en inkomsten van tagal, Samarang, damak, Japara, Jawana, Rembangh, Soerabaija, passarouang, en verdere seeplaatsen met het regt van het presidie en oeffeninge van andere terrietoriaale Reghten.

11.

Laatstelijk is door ons nogh goedgevonden en verstaan UE bij dese instructie te commandeeren om ingevalle den vorst tot geene Reedelijke conditien te overtreeden en voorsz. voorwaarden niet begeerde te accepteeren dewelke nogtans veel gunstiger zijn dan den toestand 
de hand wijzen maar deselve 't zij ten vollen of bij aldien het Uhoog Edelheden $^{s}$ omtrent de poincten door ons voorgedragen behaagde Eenige versaghtinge gebruijken na UhoogEdelgroot agtb. genoegen tot herstelling der gewenste rust en vreede amplecteeren, want wij behoeven UhoogEdelhedens niet langer op te houden omtrent de swaarigheden over het voortzetten van den oorlogh dewijl Behalven het onbegrijpel. groot aantal zieken en doden, die geduurende de laatste twee maanden onse maght meer als den oorlogh selfs verswakt hebben en dus niet weijnigh Europeesche Recruten souden verEijscht worden, Uhoog Edelhed" niet onbewust sijn hoe den oorlogh in dese gewesten niet alleen gebrek aan de nodigste levensmiddelen het toelaten verval der landbouw en de verdere ruine van land en inwoonderen na sigh slepen maar ook de lasten des oorloghs dagelijks accresseeren den keijzer hoe langs hoe meer buijten staat gesteld word dezetve te voldoen dog wanneer aan d'andere kant sijn hoogheijd na geen billijke Reedenen wilde luijsteren en de noodsake vereijschte tot gevoeliger middelen over te gaan zullen wij niet nalaten al verder met verEijschte sorgvuldigheijd $U$ hoog Edelheeds g'eerde ordres tragten op te volgen 't zij omtrend de publicatie van het bereedts gezonden manifest als omtrend het vंoortsetten deser Reghtmatigen oorlogh.

En wanneer het zoover gekomen is, dat den in dezen hier voor 't nederigsten neder gestelde vreedensarticulen met behoorlijke voorzigtigheijd en na tijdtsgelegenth. voor- zijner saken hem kunnen doen hoopen mitsgaders bij bevinding van sijne ongenegenh ${ }^{d}$ tot het aangaan van eenig vreedenstractaat met de nederlandsche maatschappij dat is te seggen wanneer hij niets van de vorenstaande pretentien begeert in te willigen alsdan het bereids derwaarts gesonden manifeste ten eersten te laten publiceeren en affigeeren mitsgads den oorlogh tegen den soesoehoenang met alle ernst en vigeur voort te zetten ten eijnde sijn hooght door geen andere middelen tot vreede te persuadeeren sijnde door de wapenen tot Redelijkheijt en Bedaren te brengen. 
gesteld kunnen worden zullen wij niet manqueeren schuldpligtig bij alle occagien UhoogEdelheeds van onze verrigtingen kennis te geven.

Samarang den 20 Jann. 1742. (was geteekend) $h^{\circ}$ Verijsel. J. h. theling. 
Eerbiedig berigt door ons ondergeteekende commissianten aan den Eagtb. heer hugo verijsel commissaris over Java's Noord oostcust, den Edagtb. heer Joan harm Theling oud eerste oppercoopman des casteels en tweede in opgem. Commissie Benevens den Edagtb. Nathanael Steinmets commandeur en veldoverste Betreffende onse ontmoetinge en wedervaren, sedert onze vlugt van Cartasoera tot onse aankomst alhier den $22^{\mathrm{e}}$ deser.

Edele Agtb. heeren

Nadien wij d'eere hebben gehad geduurende ons aanwesen aan het Keijserlijke hoff U.Ed.agtb. van tijd tot tijd bij onse submisse letteren te Bedeelen, onse verrigtinge in voldoening Uwer Ed. Agtb. aan ons ter hand gestelde schriftelijke instructie de dagteekening 13 Maart deses jaars, mitsgaders de verdere aan ons gedemandeerde bevelen concerneerende de commissie, zoo sullen wij in hope van gunstige weldduijding ons aan deselve refereeren en eenelijk bij desen noteeren dat sedert onse laatste nedrige missive in dato 29 Junij waar bij wij d'Eere hadden U.Ed.agtb. kortelijk te communiceeren de totale nederlaag van den radeen aria Pringalaya en den slegten toestand van het hoff dog aangesien meermd. Brieff $\mathrm{Zijn}$ addres niet heeft Erlangd, en wij niet in staat sijn dies minuut aan U.Ed.agtb. te konnen produceeren vermits het agter laten onser effecten en papieren door de schielijke vlugt der keijserlijke residentiestad soo sullen wij d'Eer hebben onse dagelijxe aanteekening alhier ter neder te stellen en beginnen met

Donderdag den 28 Junij's agtermiddags wanneer de klocke 4 uuren een gandek bij ons quam vande negorij Sengarang brengende berigt dat de op Salatiga bij een gerot sijnde rebelleerende Chinesen en malcontente Javanen vandaar opgebroken en in aantogt waren na Cartasoera hebbende reeds d'opbovengenoemd: negorij gecampeerd gew. ${ }^{\mathrm{e}}$. tommongongs radja nitie, mankoe juda, mankoe pradja en natta Juda op de vlugt geslagen enden omtrent den ampel gelegerde radeen aria Pringalaija na een swaar gevegt met agterlating van vele dooden tot boeijalalie genoodsaakt te retireeren.

In het vallen van den avond maakte ons bekend den tommongong wiradjaja dat gem. radeen aria pringalaija op boeijalalie 
door woedende parthij verder g'attacqueert en totaal geslagen was geworden hebbende denselven met een gering getal van sijne magt tot aan de tammerindeboom moeten retireeren, voorts nam van hier alles de vlugt soo dat selv het agterhoff ten eenemaal bloot en sonder wagt bleev.

ten 6 uuren liet den soesoehoenang den eerst geteeckende bij hem ontbieden en vraagde denselven wat bij dese nare en droevige gesteldheijd van tijd te doen en hoe het best aan te leggen was om dit groot dreijgende gevaar te ontvlieden en niet in handen der rebellen te vallen waarop denselven sijn majt. aanrade het hoff te verlaten en ten Eersten met sijn famielje en kostelijkheden Samarang w. ts. te vlugten verseekerende sijn hoogheijd van scomp. protexie hetwelk den soesoehoenang approbeerde hebbende ten Eersten de wegen na de Mattaram en Cadoe laten examineeren en verder des nagts alle zijne kostelijkheden in packten, ten 8 uuren den eerstgeteeckende thuis gekomen wesende pacten s'comp. papieren in en maakten ons mede tot het vlugten gereed; ten 9 uuren liet den soesoehoenang alle sijne onderdanen int geweer trecken en deelde onder haar veel geld uijt, sagen 'snagts een sware brand de weg op na boeijalalie.

Vrijdag den $29 \mathrm{~d}^{\circ}$. 'smorgens ten 7 uuren ging den eerst geteeckende na 't hoff en vond den Keijser met sijn famielje tot het wegvlugten gereed, dog kort hierop tijding gekregen hebbende dat alle passagies na Samarang reeds door de rebellen beset waren resolveerde sijn majesteijd hier van af te sien en op het instantig aanhouden van den oud Japaras pattij tsitrasoema en den tommongong wiradjaja de geheele vlugt soo lang uijt te stellen en af te wagten wat voordeelen de princengebroeders op den vijand quamen te behalen en ten 8 uuren vertrocken alle de princen met haare volckeren na het leger van den radeen aria pringalaija ook ging den eerst geteeckende op het versoek van den soesoehoenang na het bovengen ${ }^{\mathrm{e}}$. leger soo om hetselve te besigtigen als om de princen en verdere ministers uijt name van sijn hoogheijd tot haar pligt aan tesetten, ten 10 uuren sonden wij een sendeling (sijnde een maleijer) in name lemboe na het leger den welcken des agtermiddags reverteerde met tijding dat het leger hooger opgerukt was hebbende de rebellen tot boeijalalie alsmede op Cartasoera sijnde dien nagt den dalm van radeen wiradiningrat (soon van den adepattij natta Coesoema) afgebrand, maakten een comp. brieff in gereedheijd waarbij wij de totale nederlage van radeen aria pringalaija en de ware toestand van het hoff aan de agtb. heeren commissarissen en commandeur communiceerden en sonden deselve op. 
Saturdag den $30 \mathrm{~d}^{\circ}$. met het aanbreken van den dag met een gandek na Samarang. ook sonden voorm. sendeling lemboe weder na het leger tot banjadana dewelcke ten 10 uuren weder reverteerde met berigt dat de rebelleerende Chinesen g'accompagneerd met Eenige vaandels malcontente Javanen in 2 parthijen verdeelt op het leger quamen afsacken, sonden denselven ten Eersten wederom met order om verder op alles nauwkeurig te letten en bijtijds van alles kennis te geven denwelcke ten 12 uuren gereverteerd sijnde relateerde gesien te hebben, dat d'Eene parthij der rebellen reeds alle de princen op de vlugt geslagen en door de rijstvelden (terwijle d'andere parthij met radeen aria pringalaya nog sterk doende was) na Cartasoera quam afsacken, voorts quam den tommongong wiradjaja ons dese bedroefde en slegte tijding bekend maken en versogt ons ten Eersten met al het volk na het hoff te gaan, waarop wij ons opstonds met 's comps. papieren en onse goederen (soo veel ons mogelijk was mede te neemen) na den keijser begaven en vonden denselven voor de binnenste poort van sijn hoff met een piek in de hand staan, dewelcke ons met de tranen in d' oogen vraagde wat bij dese droevige gesteldheijt en groot gevaar te doen was, waarop den Eerstgeteeckende sijn majt. in antwoord diende niets anders te weten als dat sijn hoogheijd sig soodra als immers mogelijk van den reeds voor 3 dagen gedanen voorslag geliefde te bedienen, sijnde het gansch niet raadsaam, dat sijn majt. met sijn famielje hier tusschen dese muuren een minuut langer vertoefde als lopende gevaar nevens ons door de rebellen besprongen te worden, hierop liet den soesoehoenang sijne magthebbende volckeren bestaande wel uit 2000 mantries in sijn dalm trecken en poorten van het voorhoff sluijten voorts sijne moeder besorgd (dewelcke vermits hare geduurende flauwtens niet konden te peerd rijden door 2 Europ. gedragen wierd) sijn suster vrouwen en kinderen op de peerden geholpen hebbende begaven ons onder Een groot gehuijl en gelamenteer der vrouwl. na de agterpoorten van het hoff, vermeenende daardoor agteruijt te gaan, d' Eerste van voorne. poorten met veel moeijte groot gedrang en niet min groot gevaar door de veelheijd van pieken daarmede de vlugtende Javanen verscheijde swaar gequest hebben, gepasseert sijnde hoorden aan de tweede komende de rebellen op de passebaan lemmadoehoer en reets binnen den dalm uijt bassen en snaphanen sterk in de huijsen vuuren waarop sig Een ijder na het agterhoff haaste en van het gene hij te dragen had ontlaste sijnde bijna door de menigte sacken met geld, packen met goud en silver, goude betel Cousetten Bekers en andere Dl. 74 . 
kostiglijkheden den verdere doorgang na het agterhoff gestopt (de ratoe amancoerat die tot dusverre door 2 Europ. gedragen wierd, is alhier op haar instantig versoek te peerd gaan sitten) dog na seer veel moeijte aan de laatste poort gekomen sijnde bevonden dat dese reeds gesloten en van buijten door de rebellen beset was, dewelcke ons ten Eersten met Eenige schoten uijt bassen en snaphanen begroeten, waarop alle ons nog tot dusverre gevolgd sijnde Javanen ten Eersten de vlugt over de hooge muuren namen hebbende ons alleen nevens den Keijser en sijn famielje onder Een groot gedrang en gekerm van Eenige duijsend vrouwl. in de uijtterste verlegenth ${ }^{\mathbf{d}}$ gelaten, hetwelk de rebellen bemerkt hebbende ten Eersten haar schoten verdubbelde en onder de bij ons sijnde vrouwl. sterk met voetsoekers begonnen te goijen, waardoor deselve in d'uijtterste verwarring geraakten, verscheijde van des Keijsers vrouwen, dic tot dusverre te peerd gereden hadden, hier het ongeluk van af te vallen en haar swaar te quetsen waarop het jammeren en lammenteeren verdubbelde. Een ijder wilde gaarn het drijgend gevaar ontloopen dog het klimmen over de hoge muren was soo wel voor den Keijser als ons onmogelijk gelijk mede het openen der passagie door de geringh ${ }^{d}$. onser magt. over sulx wij onse retraite namen na Eene kleijne opening in de buijtenste muur van den dalm die met spaanse ruijters en voetangels beset was, waar dat den soesoehoenang het ongeluk hadde sijn peerd te verliesen en den Eerstonderget. dierhalven genoodsaakt sijn hoogheijd op de schouders na buijten te slepen tot op de rijstvelden alwaar een peert bequam daar wij den keijser opsetten, intusschen dat den pangerang depattij anum door een Javaan vooruijt lieten dragen met voornemen onse cours na de rivier Solo te nemen om dus in een prauw na Sourabaija af te sacken, maar tijding krijgende dat martapoera met 500 man in aantogt was om gene. rivier te passeeren veranderden wij van voornemen en passeerden in het vallen van den avond bij mangarang de meer geciteerde rivier Solo met intentie om ons over magittan na Sourabaija te begeven en hielden onse nagtrust op de negorij tradjicoenincq. alwaar sig den soesoehoenang met sijn soon seer armoedig heeft moeten behelpen en geen ander hoofdcussen hadde dan het sadel van den Eerstgeteeck. sijn paard, in desen ongewoonelijken en verdrietigen staat beklaagde sig den vorst niet soo seer over sijne schatten als wel over het agterlaten van desselvs famielje, betuijgende wanneer hij eens wederom den throon quam te beklimmen zijn Hoogheijd noit gedoogen soude dat de chinesen sig in het rijk van Java ophielden. 
voorts depecheerden Een brieff aan het hoofd tot Sourabaija met versoek om onse vlugt aan d'Ed. Agtb. heeren Commissarissen te communiceeren sonden verders 4 Javanen uijt om na d'agtergelatene Keijserlijke famielje te vernemen ter welker gelegenth ${ }^{d}$. den laatstgeteeck. zijn Majt. Eenig geld leende ende vermits denselven nog geene der verdere Europ. met de schielijke vlugt verdagt waren geweest om sig daarvan te voorsien.

Sondag den 1 Julij des nagts ten halv 3 uuren braken van voorn. negorij op en quamen des avonds ten 6 uuren na door sware Bosschen en ontoegankelijke gebergtens en zwaare valeijen meest te voet gemarcheerd te hebben op de negorij goeger gelegen op een hoogen berg alwaer het hooft van magittan tsitra diwiria met al sijn volk bij ons quam.

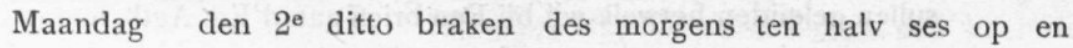
quamen na als daags bevorens door sware wegen gemarcheerd te hebben des middags ten 12 uuren op de negorij pantjot moesten alhier door den sware regen overnagten.

Dingsdag den 3 ditto des morgens ten halv 6 uuren gingen op marsch over het sware gebergte lawoe en quamen ten 11 uuren op Een negorij gen. lawang alwaar Een weijnig rusten en onse reijs verder voortsetten na het landschap magittan daar wij ten halv 5 uuren aanquamen.

Woensdag den $4^{\mathrm{e}}$ d $^{\mathrm{o}}$. schrijven een brieff aan d'Agtb. Heeren commissarissen en commandeur ter bekend making van 's Keijsers en onse vlugt depecheerde wijders Een brieff aan de tot Djipan gecampeerde madurese legerhoofden met versoek om ons van madioen af te halen en verders tot sourabaija te geleijden alsoo wij tijding hadde bekomen dat sig Een getal van 100 Chinesen op de negorij awie onthielden. hier quamen bij ons de hoofden van madion martalaija en soemawidjaja met een gedeelte van haar volk, dewelcke sijn majt. begunstigde als van ouds met de namen van pangerangs, voorts quam alhier Een ola van den radeen mangonona aan sijn Hoogheijd behelsende dat desselvs moeder, kinderen en voorts alles in der vijanden handen gevallen was alsmede dat de volgende 4 princen zig den nieuwen keijser onderworpen hadden als boeminata, aria mattaram, singosarij en aria pannoelaar.

Donderdag den $5^{\mathrm{e}} \mathrm{d}^{\mathrm{o}}$. braken des morgens ten 7 uuren op en vorderden (onse) reijs naar madion daar wij in den agtermiddag ter 4 uuren aanquamen alhier stelde sijn Hoogheijd een nieuw hoofd aan van Cadirie. 


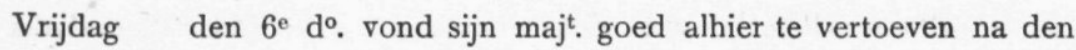
tommongong Soerabrata van panaraga denwelcken des middags nevens het hoofd van tjaroeban alhier aanquam.

Saturdag den $7^{\mathrm{e}} \mathrm{d}^{\mathrm{o}}$. sloeg den tommongong Soerabrata den soesoe-

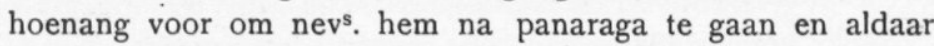
te vertoeven waarop den Eerstget. sijn majt. versogt om de reijse dog met den Eersten na Sourabaija voort te setten dog op de kragtigste verseeckeringen van meergen ${ }^{d}$. tommongongs goede intentie resolveerende den keijser en wij met hem na panaraga te trecken temeer wij tijding kregen dat maas brahim de wegen over tjaroekan na soerabaija beset had en wij nog geen antwoord op ons schrijvens van de madurese hoofden tot djipan hadden, voorts versoekende meer geciteerde tommongong ons door de mattaram en cadoe na Samarang te sullen geleijden hetwelk wij bij Een brieff aan d'Ed. Agtb. heeren commissarissen en commandeurs alsmede aan het hoofd tot sourabaija en de madurese legerhoofden tot djipan Bekend stelden.

Sondag den $8^{e} d^{o}$. vertrocken van madion des morgs ten 7 uuren en quamen ten halv twaalv op Een plaats in 't bosch alwaar ten tijde doen Java in 4 koningrijken verdeelt was den ratoe galang sijn hoff gehouden heeft, aten hier een weijnig en ten twaalf uuren vorderden onze reijs na panaraga daar wij ten 5 uuren aanquamen.

Maandag den $9^{\mathrm{e}} \mathrm{d}^{\mathrm{o}}$. quamen alhier het hooft van Awie (zijnde voor desen een Chinees geweest), dewelcke sijn hoogheijd tot ingabeij aanstelde.

Dingsdag den 10 ditto vertrocken de hoofden van madion en awie na hunne plaatsen om hun volk bij malkander te versamelen zig digt onder Cartasoera te posteeren, quam een spion terug van Cartasoera relateerde dat het hoff voor het grootste gegedeelte was afgebrant en dat nog weijnig Javanen sig aan den nieuwen Keijser onderworpen hadden, voorts dat het getal der chinesen aldaar niet Boven Een duijsend was.

Woensdag den $11^{\mathrm{e}}$ ditto arriveerde alhier de hoofden van magittan, djipan en lamongang voorts resolveerde sijn hoogheijd op het kragtig aanhouden van den tommongong soerabrata alhier te verblyven tot aanstaande Dingsdag.

Donderdag den 12 ditto niets voorgevallen.

Vrijdag den $13^{e}$ ditto arriveerde alhier den ingabij Soetanagara van Cadoean tijding brengende dat den tommongong wiradjaja in 
het vlugten door de Chinesen was agterhaald en gevangen genomen alsmede dat de chinesen met den nieuwen keijser een accoord hadden gemaakt dat zijlieden 3 dagen het com mando tot Cartasoera souden hebben en dat naderhand de regeering aan den nieuwen keijser soude opgedragen worden.

Saturdag den $14^{\mathrm{e}} \mathrm{d}^{\circ}$. niets voorgevallen.

Sondag den $15^{\mathrm{e}} \mathrm{d}^{\circ}$. als voren.

Maandag den $16^{\mathrm{e}} \mathrm{d}^{\mathrm{o}}$. wierd alhier tijding van Cartasoera aangebragt dat panjang en mangoenoneng geresolveerd hadden Een gesantschap aan den vlugtigen keijser af te senden en hem voor te slaan dat wanneer sijn majt. de stranden wilde afstaan aan de Chinesen en voorts een goed accoord met hem sluijten zij gesind waren sijn hoogheijd met 2 oliphanten in alle statie aan het hoff in te halen en Erkennen hem voor haren souverain waarop sijn majt. Betuijgde dat wanneer Eenen van haar de hardiesse had van onder sijn oogen te komen hij in stede van een accoord te sluijten haar aanstonds soude laten om hals brengen.

Dingsdag den $17^{\mathrm{e}} \mathrm{d}^{\mathrm{o}}$. vertrocken van hier panaraga des morgens ten 7 uuren quamen ten 11 uuren voormiddags op Een negorij gen. Menang alwaar dien nagt bleven slapen.

Woensdag den $18^{e}$ ditto Bleven alhier dien dag stil.

Donderdag $19^{\mathrm{e}} \mathrm{d}^{\circ}$. gingen des morgens ten 7 uuren opmarsch en quamen ten 12 uuren op een plaats in Een swaar bosch gend. Brankal alwaar Eenige hutten opgeslagen wierden en wij onse nagtrust hielden.

Vrijdag den $20 \mathrm{~d}^{\circ}$. bleven hier stil om nog Eenige volckeren af te wagten.

Saturdag den $21^{\mathrm{e}}$ als voren quamen bij ons den pangerang aria pamot.

Sondag den $22^{\mathrm{e}} \mathrm{d}^{\mathrm{o}}$. gingen des morgens ten 7 uuren van hier en quamen ten Elv uuren op Een plaats gen. tierisan alwaar wij bleven slapen.

Maandag den $23^{\circ} \mathrm{d}^{\mathrm{o}}$. braken des morgens ten halv 7 uuren en quamen na door seer gevaarlijke wegen gepasseert te hebben in den agtermiddag ten 2 uuren op Een plaats in het bosch gen. Wattas makkten hier weder Eenige hutten en Bleven daar dien nagt slapen.

Dingsdag den $24 \mathrm{~d}^{\mathrm{o}}$. des morg* ten halv 7 uuren gingen op marsch weder door seer slegte wegen en quamen ten halv 10 uuren op een plaats geheeten tandoeran Cadoean gelegen op Een 
seer smakelijke heuvel alwaar voor desen den soesoehoenan pacoeboeana met 's-Comps. volckeren sijn verblijv Eenige maanden heeft gehouden, aten hier Een weijnig en vervorderden onse weg na Cadoean alwaar wij te halv twaalf aanquamen.

Woensdag den $25^{\mathrm{e}} \mathrm{d}^{\mathrm{o}}$. kregen tijding van Cartasoera dat den pangerang ingabij zig den nieuwen keijser onderworpen had en dat den tommongong radjenitie en oud pattij Tsitra Soema van de vijanden gevangen.

Donderdag den $26^{\mathrm{e}} \mathrm{d}^{\circ}$. niets voorgevallen.

Vrijdag den $27^{\mathrm{e}} \mathrm{d}^{\mathrm{o}}$. quamen pangerang diepanagara en radeen aria pringalaija met hunne vrouwen en kinderen bij ons.

Saturdag den $28^{\circ} \mathrm{d}^{\circ}$. quam alhier een spion terug van Cartasoera relateerde dat het leger van de Comp. reeds damak, pattij en grobogan had ingenomen verws . vele chinesen en javanen van cartasoera waren na toe getrocken ook dat panjang op laastgen. plaats gestorven was voorts wierd alhier gespargeerd dat den pangerang pourbaija op Samarang en de Comp. van sints was denselven op de mattaramse throon te setten, alsmede dat den gew. rijxbestierder danoeredja weder in sijn vorige plaats aangesteld was en het bewind over het leger tot damak had, welcke gerugten Een seer groote verslagenheijd onder de bij sijn majesteijd sijnde hoofden baarden, ook kregen tijding dat de pangerangs van Madion slaags hadden geweest met de vijanden die ons meenen te vervolgen ende victorie bevogten hadden verders versogt den tommongong Soerabrata en verdere bij sijn Hoogheijd sijnde hoofden den Keijser op het instantigst om permissie te mogen hebben op de zig tot Cartasoera onthoudende rebellen een attacque te wagen voorgevendesig niet te durven bij dese gevaarlijke conjunctuure van tijd uijt hun land te begeven en sijn majesteijd door de mattaram en cadoe na samarang te geleijden en alschoon den soesoehoenang en wij haar voorhielden van d'uijtterst noodsackelijkheijd te sijn dat den keijser Eerst gesecureerd en in veijligheijd gebragt wierd soo hebben egter niets op haar konnen winnen verseeckerende ons teffens dat sig voor sijn majt. als haren wettigen souverain tot de laatste man als mede voor de Comp. te willen vegten aan welk besluijt wij ons geduldig hebben moeten onderwerpen, maakten een brieff klaar aan d'Ed. agtb. Heeren commissarissen en commandeur en sonden deselve nevens Een brief van den Keijser op.

Sondag den 29 do. na Samarang. 
Maandag den $30 \mathrm{~d}^{\circ}$. sond Martapoera Een afdeeling aan den tommongong Soerabrata met versoek bij aldien denselven borgh voor sijn leven wilde sijn hij alsdan van sints was sig den vlugtigen keijser te onderwerpen, die hij bekende door onkunde geled $^{\mathrm{n}}$. te hebben sig verbeeldende dat d'orders van den radeen depattij Natta Coesoema bevelen van sijn majt. waren en kregen verders tijding dat mangononenging sig niet langer met de saacken wilde bemoeijen maar sijn plaats overgegeven had aan de pangerang boeminata.

Dingsdag den $31 \mathrm{~d}^{\circ}$. vertrocken tommongong Soerabrata met sijn geheele leger nade negorij Oeter.

Woensdag den 1 Augustus niets voorgevallen.

Donderdag den $2^{e}$ ditto als vorens.

Vrijdag den $3^{e}$ ditto kregen tijding dat de hoofden van madion weder slaags hadden geweest, met verlies van 30 dooden genoodsaakt te retireeren waarop ons door Een spion van Cartasoera werd berigt dat de bekomene nederlaag sulk een schrik onder de vijanden had gebragt dat mangononeng den gewaanden rijxbestierder de vlugt na sijn regentschap pattij me[en] de te nemen sonder sig te kunnen [kreunen] aan maas grendie, die hem versogt te mogen vergeselschappen aangesien Een ijder hem verliet en hij niet tot keijser geboren waar, maar Eenelijk door hun daartoe angesteld.

Saturdag den 4 ditto quam van Cartasoera bij ons den tommongong radja nitie met sijn vrouw en kinderen die sijn hoogheijd al huijlende om Excuus versogt en bekende grootenlijx tegens hem gepexeerd te hebben door het geven van sijn woord aan den radeen adepattij Natta Coesoema die door het dethrooneeren van den wettigen vorst sig selvs vermeende tot keijser op te werpen, dat tot dien Eijnde maas grendie als Een speelpop en dekmantel van sijn voornemen streckte aan wien hij (na berijking van sijn oogmerk) benevens panjang de westerstranden tot een recompens vermeende te geven.

Sondag den $5^{\mathrm{e}} \mathrm{d}^{\mathrm{o}}$. quam een sendeling van den tommongong Soerabrata met een brieff aan sijn majt. behelsende dat denselven gisteren morgen met de vijanden was in gevegt geraakt en deselve op de vlugt had geslagen met agterlating van 50 dooden, 20 stucken waaronder Eenige sware canons en 50 snaphanen, sonder dat van sijn kant Eenige gebleven was.

Maandag den $6^{\circ}$ kregen tijding van Cartasoera dat den pangerang boeminata van daar was gevlugt en dat den nieuwen keijser 
sig niet langer binnen het hoff vertrouwde, maar in het huijs van den pangerang ingabij getrocken was, voorts quamen hier de sendelingen van de hoofden tot soerabaija Sawongaling en wiro serojo brengende Eenige geschenken voor den keijser, ook berigten gen. sendelingen sijn majt. dat maas brahim een sendeling aan meer gen. Soerabaijse hoofden had gesonden ten Eijnde bij haar te vernemen off hij ook sijn hoogheijd met sijn magt konde adsisteeren en dat wanneer sijn hoogheijd sijn adsistentie requireerde hij ten Eersten bereijd was sijn maj.t met 1000 man bij te springen, waarop zijn hoogheijd aan gen. sendelingen betuijgde niet gesind te sijn maas Brahim nog een ander tot sijn hulp te roepen stellende allen sijn vertrouwen op de Comp.

Dingsdag den $7^{e} \mathrm{~d}^{\mathrm{o}}$. kregen des agtermiddags ten 4 uuren tijding dat den tommongong Soerabrata met sijn geheele leger geslagen en dat de vijanden reeds digt bij genadert waren, waarop wij alle nevens den keijser en den kroonprins de vlugt van hier namen en quamen dien avond op watt[a]s alwaar wij tijding kregen dat den tommongong soerabrata met sijn nog bij hem hebbende mans geretireert was tot tandoeran Cadoean, bleven alhier dien nagt onder den blooten hemel campeeren sloegen sijn hoogheijd nogmaals voor dat dog hoe Eer hoe liever de reijse na Soerabaija geliefde voort te setten, alsoo sijn majt. genoeg kon sien wat staat hij op sijn onderdanen kon maken daar sijn majt. niet ongenegen toe scheen, maar alvorens daarover met den tommongong Soerabrata op pranagara wilde delibereren.

Woensdag den $8^{e} \mathrm{~d}^{\mathrm{o}}$. smorgens ten half 4 uuren gingen op weg, passeerden brancal en quamen ten 8 uuren op pranagara, alwaar een weijnig daarna den tommongong Soerabrata meede arriveerde.

Donderdag den $9^{\text {e }} \mathrm{d}^{\mathrm{o}}$. sloeg den keijser aan de bij hem hebbende Javaanse Regenten (voor) voornemens te sijn sig met ons na sourabaija te begeven, waarop meerm. hoofden zijn hoogheijd vertoonden dat desselvs vertreck van seer hachelijke gevolgen soude kunnen sijn, soo ten aansien der wel g'intentioneerde javanen die sig opstonds aan maas grendie souden onderwerpen, als ten opsigte van svorsten Eijgen persoon en hij hem hebbende geselschap die seeckerlijk door de Javanen zouden versogt werden, daarentegen wanneer sijn maj.t van voornemen wilde veranderen hij tommongong soerabrata aannam den vorst in het gebergte soo wel te sullen verseeckeren dat geene vijanden hem souden kunnen ontdecken en wijders sijn volk sou tragten bij Een te versamelen om op de minste beweging van de Comp. den vijand wederom aan te tasten, 
mitsg. den vorst niet sou verlaten als ten kosten van sijn leven, dat hij in ons aller bijsijn met solemmeelen Eed heeft bekragtigd, waarop den keijser besloot zig int gebergte te begeven en in onse keur stelden of wij hem wilden volgen dan wel na sourabaija vertrecken om dus mondeling op samarang verslag te kunnen doen aan d'Ed. Agtb. heeren commissarissen en commandeur van sijn bedroefden staat en aangesien den meerm. tommongong Soerabrata bedugt was dat den keijser door ons int gebergte mogt ontdeckt worden, soo besloten wij onse reijs Sourabaija w.ts. voort te setten onder een Escorte van 50 à 60 man Soerabaijse Javanen.

Vrijdag den $10^{e}$ ditto 's morgens ten 7 uuren stelde sijn majt. en den tommongong Soerabrata den Eerstonderget. ijder I en brieff ter hand beijde aan de Ed. Agtb. heeren commissarissen en commandeur gerigt om die persoon adres te verleenen met instantig versoek om door haar meerm. haar Ed. agtb. op het allerspoedigste geholpen en in sijn keijserlijke residentie stad te werden hersteld met verdere Betuijging ingevalle de Comp. zijn hoogheijd de door hem gerequireerde adjude te bewijsen hij soodanig Een contract met de Comp. te willen sluijten als die hem quam voor te leggen, verders betuijgd zijnde dat de 2 Ingabijs Sawongaling en Wiroserojo tot Sourabaija sig de gehoorsaamheijd van maas grendie mogten onderwerpen, besloot sijn majesteijt deselve tot costij als hoofiden aan te stellen in stede van d'ingabijs Setjadirana en Soerengrana met ordre om het opperhoofd hiervan de vereijschte kennis te geven, waarop wij van sijn hoogheijd den kroonprins en verdere regenten affscheijd namen die ons versogten d'Ed.agtb. heeren commissarissen en commandeur van hun agting en goede intentie te verseeckeren, met bede geen geloof te willen slaan aan nadeelige gerugten alsoo geen van alle voornemens waren het belangen der E. Comp. te verlaten Betuijgende den radeen aria pringalaija in het bijsonder, voornemens te sijn bij aldien hij bespeurde dat den keijser van gedagten veranderde denselve Eijgenhandig om het leven te sullen brengen, vervolgens verlieten wij benev ${ }^{\mathrm{s}} 2$ keijsers mantries in namen Sindepattij en Nolloderidjo panaraga en quamen ten 6 uuren des avonds op de negorije pagoe daar wij dien nagt vertoefden.

Saturdag den $11 \mathrm{~d}^{\circ}$. gingen des smorgens ten halv 6 van daar en arriveerden in den agtermiddag ten 3 uuren op Tjeroeban.

Sondag den $12^{\mathrm{e}} \mathrm{d}^{\mathrm{o}}$. braken des morgens ten 5 uuren op, geraackten des avonds ten 9 uuren op Kotta beda, van waar 
Maandag den $13^{\circ} \mathrm{d}^{\circ}$. met het aanbreken van den dag op marsch gingen en passeerden om 11 uur de rivier Solo bij imbra en arriveerden ten 3 uuren des agtermiddags op de negorij Oenong.

Dingsdag den $14^{\mathrm{e}} \mathrm{d}^{\mathrm{o}}$. vertrocken in den morgenstond om 6 uuren na de negorij marong alwaar wij des agtermiddags ten 3 uuren aanquamen.

Woensdag den $15^{e} \mathrm{~d}^{0}$. des morgens ten 6 uuren setten onsen reijs voort na de negorij Boeka waar wij des agtermiddags ten 4 uuren aanlanden.

Donderdag den $16^{\mathrm{e}} \mathrm{d}^{\mathrm{o}}$. begaven ons ten 6 uuren op weg en quamen des agtermiddags ten 4 uuren op de negorije Tanoes.

Vrijdag den $17^{\mathrm{e}} \mathrm{d}^{\mathrm{o}}$. ging(en) des morgens met het aanbreken van den dag op marsch, arriveerden de klocke agt uuren op een digt bij Soerabaija leggende negorij van waar door de van den soesoehoenang nieuw aangestelde hoofden Sawongaling en Wiro Serojo wierden afgehaald en dus na de Soerabaijse logie Begeleijd.

Saturdag den $18^{\mathrm{e}} \mathrm{d}^{\mathrm{o}}$. Embarcqueerden ons des agtermiddags ten vier uuren in de chialoep d'Overwal waarmede na dien selven avond onder seijl gingen en quamen op

Woensdag den $22^{\mathrm{e}}$ ditto behouden op Samarang alwaar wij d'Eere hadden UEd. agtb. ter hand te stellen 's keijsers missive en Een ditto van den tommongong Soerabrata mitsg's. 's Comps. brieff van het opperhoofd aldaar Benevens eene van de commissianten Rhenerts en Duijt.

Hiermede verhopen wij aan UE. agtb. hoog g'Eerde order en intentie voldaan te hebben Kn betuijgen met diep schuldige F erbied te zijn (onderstond) Edele agtbare heeren (lager) UEd. agtb. onderdanige en seer gehoorsame dienaren.

(was geteekend) J. A. V. Hohendorff en C. F. Hogewits. (in margine) Samarang den 25 Augustus 1742.

(daaronder) accordeert (get.) J. v. n. Suchtelen. Comm. Sec ${ }^{\text {s. }}$ 
Consideratiën en Remarcques van Joan Andries van Hohendorff eerst gewesene Commissiant aan het Cartasoerase hoff, nopens den keijser Pacoeboeana en desselvs ministers opgedragen aan d'Ed. agtb. heeren Hugo Verijsel commissaris over gands Javas N. O. cust Joan herman Theling tweede in opgem. Commissie benevens Nathanael Steinmetsz commandeur en veldoverste.

\section{Edele Agtbare Heeren.}

Uijt het bereeds aan UEd. agtb. ter hand gestelde dagregister in dato 25 deser zal UEd. agtb. sijn gebleken de schielijke en onverwagte vlugt van het Cartasoerase hoff met agterlating onser geringe Effecten en Comps. papieren waardoor ik buijten staat ben gesteld behoorlijk van rapport te kunnen dienen op de door UEd agtb. aan mij gedemandeerde commissie, des niettemin heb ik van mijn pligt g'acht in dese duijstere en verwarde gesteldheijd van het Javasche rijk mijne geringe bedenkingen en onpartijdige aanmerkingen soo ten aansien van den vorst als desselvs ministers bij wijse van rapport onder de Benaming van Consideratiën en Remarques alhier ter neder te stellen off die ook somtijds Eenige opmerkingen bij UEd. agtb. verdiende en in derselver hoogwigtige commissie van nut konde sijn in welckers verwagting ik Een aanvang zal maken met den Keijser Pacoeboeana, die van het oogenblik mijner komste aan desselvs hoff tot mijn vertrek van pranaraga, alwaar ik sijn hoogheijd heb verlaten noit andere blijken heevt gegeven. dan van Een opregte welmeenendheijd en standvastige trouw voor de Comp. gelijk ik sulx heb moeten Besluijten uijt de prompte ordres die sijn majesteijt successivelijk op mijn instantig versoek aan desselvs ministers en verdere onderdanen heevt uijtgedeelt, hetgeen mij altoos Een onwrickbaar blijk is geweest van sijn goede intentie en ofschoon meerm. orders dikwijls gebreckelijk dan wel int geheel niet ten uijtvoer sijn gebragt gelijk men sulx eerst heevt kunnen ontwaren na de detentie van den radeen adepattij Natta Coesoema zoo dient dies versuijm veel Eer aan den sinistren rijxbestierder en andere quade g'intentioneerde dan aan den soesoehoenang toegesch. te werden, in voegen als UEd. agtb. sal komen te blijken uijt den inkoop der recognitierijst waartoe zijn majest. in mijn bijsijn de benoodigde contanten uijt sijn Eijgen cassa verstrekt en tot den insaam van dien corl d'ingabijs Soeramangala en anong aangesteld heeft die in stede van aan sijn hoogheijds bevelen 
te voldoen door radeen adepattij voornd. opontboden en in sijn leger aangehouden sijn dat sijn majesteijt niet Eerder heevt ontdeckt dan na het in apprehensie nemen van den rijxbestierder, wanneer de soon van den tommongong radja nitie in name Soeremangala ter dier gelegenheijd de vlugt na Cartasoera nam en aan sijn hoogheijdt relateerde d'Eijgenlijke reden van de trage leverantie der recognitierijst, in voegen als hiervoren vermeld staat.

Het uijtgeven sijner Edicten ter vervolging der vijandelijke Chinesen met betuijging van de dood aan de sulcke, die haar Eenig onderstand bewesen off het met deselve hielden sijn ook van weijnig vrugt geweest gelijk sulx consteert uijt de behandeling van mangononeng, patmanagara, martadipoera en martapoera, die den keijser van voornemen is geweest noijt pardon te verleenen, soo als hij meer dan Eens heevt verseeckerd.

De traagheijd van den rijxbestierder in het uijtroeijen der Chinesen en het besetten van Damak strekt mede tot Een overtuijgend blijk hoe weijnig reguard men op 'svorsten Bevelen gav niettegenstaande de gereitireerde minsame aanmaningen van $\mathrm{Zijn}$ hoog ${ }^{\mathrm{d}}$. bij desselvs missive vervat waar van mij telkens de inhoud is bedeelt, gelijk mede van Eenige Brieven door sijn majesteijt aan den tommongong Tirtawigoena gerigt waarbij den vorst sig beklaagde over de traagheijd van den veldoverste radeen adepattij die geen andere verschooningen Bij bragt dan de slegte gesteldheijd der wegen en het hooge water waardoor hij genoodsaakt was zijn opmarsch te staken, dat aanleijding gaf tot het afsenden Eener mantrie van de ratoe amancoerat in name poerbajaja om occulaire inspectie te nemen en hem radeen adepattij verder uijt name van den keijser en desselvs vrouw moeder tot sijn pligt en gedane belofte aan te manen, maar door het voordeelig rapport -van den mantrie en de goede getuijgens van den tommongong Tirtawigoena die telkens confirmeerde de bij gebragte uijtvlugten van den rijxbestierder was den keijser niettegenstaande de bij hem opgevatte suspitien genoodsaakt geloof aan het Een en ander te slaan totdat Eijndelijk de Cartasoerase wegen door de Chinesen beset wierden, en gevallig in Een tijd de door UEd. agtb. gerequireerde ostagiers Samarang waarts stonden te vertrecken wanneer sijn hoogheijd mij des avonds ten 8 uuren bij hem liet roepen, die mij betuijgde thans klaar te kunnen sien, dat sijn Eersten minister hem misleijde doordien hij den vorst verseeckerd had de Chinesen in het land van damak beset te hebben, waarop sijn majt. besloot UEd. agtb. bij Een brieff hiervan kennis te geven en met Een te versoeken soodanige middelen te willen beramen als tot voorkominge van dies trouweloose behandelingen konden Erdagt werden, dat ik hem heb afgeraden gehad uijt vrees gem. Brieff somtijds in handen van den rijxbestierder mogte vallen dan 
wel in die der Chinesen, waardoor het geheele dessin van sijn hoogheijd soude konnen veridelt worden dog om aan UEd.agtb. daarselvs over te onderhouden nademaal het niet te denken waar (ofschoon mijn Brieff onderschept wierd) hij denselven soude kunnen lesen, dat daar d'Eijgentlijke reden is sijn majesteijt desselvs besluijt ten aansien van den rijxbestierder niet schriftelijk aan UEd. agtb. heevt bedeelt maar wanneer zijn majesteijt de tijding bequam van het aanhouden van den rijxbestierder, waaren keijser en den ratoe amancoerat soodanig verheugd, dat daags daar(na) alle de princen van den Bloede benev ${ }^{8}$. den ondergeteekende in den dalm wierden genoodigt, waar dat hij den brieff door UEd. agtb. aan hem gecarteert aan de pangerangs ingabij lorring passir en boeminata produceerde en voorts een placcaat liet affigeeren ter bekendmakingen van de trouwloose behandelingen van radeen adepattij ten aansien van sijn majt. en de Comp. aan wien hij denselven overgaff en mij verders mondeling Betuijgde dien minister met de dood tot een Exempel van andere te willen straffen.

Wat nu betreft den tweeden veldheer radeen aria Pringalaija daar van kan UEd.agtb. geen andere getuijgenis geven soo uijt de rapporten als ges. brieven dan dat denselven in allen deelen d'orders van sijn majt. heeft tragten na te komen en seeckerlijk volbragt sou hebben, indien hij niet steeds de grootste magt der Chinesen op den hals had gehad gelijk hij den soesoehoenang meer dan Eens heevt ges. en nader op Cadoean (waar hij ende sijn vrouw en kinderen sonder verder gevolg bij ons quam) mondeling aan die vorst verhaalde dat terwijl den rijxbestierder in sijn campement opgesloten lag hij de Chinesen na hem toesond om waar het mogelijk pringalaija te verslaan dan wel den hals te Breken, dat hij uijt vrees voor den rijxbestierder noijt aan den keijser had durven openbaren nog de minste kennis geven van dies suspecte behandelingen aangesien de slegte bejegeningen die hij van radeen Depattij in volle Vergadering en selv in het bijsijn van sijn hoogheijd had moeten ondergaan, wanneer hij volgens sijn pligt denselven had afgeraden Samarang te belegeren en te gelijk sijn majt. gebeden sig niet te laten verleijden, dat soo hoog bij dien Eerste minister wierd opgenomen hij den keijser versogt pringalaija met de dood te willen straffen, soo als sijn hoogheijd immers bewust was, verders heb ik noijt kunnen bespeuren dat denselven Eenige verbintenis met de Chinesen aangegaan off de minste correspondentie met deselve gehouden heevt, waarin ik ben gesterkt geworden door de algemeene haat die de vijanden hem toedragen blijkens de berigten die wij op Cadoean Erlangde dat het rebellig rot voornemens was den minister levendig in de olij te koocken en sijn huijs en goed bereids aan een Chinees hadden gegeven, wiens vader pringalaya $\mathrm{a}^{\circ} \mathrm{p}^{\circ}$ in het begin der Javase troublen bij Salatiga in gesantschap na Cartasoera gesonden, 
den hals had laten breecken en denselven de naam van radeen aria pringalaija doen aannemen, van de verdere regenten tot het hoff behoorende zou ik UEd.agtb. zeer geerne een net en district denkbeeld geven, indien deselve sig niet op order van den vorst kort na mijn komst te veld hadden begeven zoodat geduurende mijn aanwesen aan het keijserlijke hoff, sig geen andere regenten aldaar hebben opgehouden dan de tommongongs wiradjaja en wiraredja beijde het ampt van hofboden bekleedende die voor sooverre mij is gebleken niets dan teeckenen van genegentheijt voor den vorst en welmenendheijd voor de Comp. hebben gegeven soo als sulx is af te nemen uijt den tommongong wiraredja, die om den keijser in sijn vlugt te versellen, sijn vrouw en kinderen en al het sijne heeft verlaten, gelijk ik Instineer dat wiradjaja almede sou hebben gedaan, indien hij niet door de vijanden was aangehouden waarvan mij de tijding op Cadoean bij mondelinge berigten Erlangde en wel met deze omstandigheijd dat wiradjaja met d'komste der Chinesen op Cartasoera na Een sijner negorijen sou sijn gevlugt en van daar sijn schoonsoon ingabij Soetanagara tot Cadoean had laten versoeken hem Een veijlige retraite te vergunnen, die sulx volkomen geweijgerd had, sooals dat quam te blijken met onse komste op Cadoean wanneer meerm. ingabij den keijser over dies refus pardon versogt en te gelijk obtineerde.

Tot dusver UEd.agtb. schuldpligtig Bedeelt te hebben hetgene mij van de hiervoren geciteerde minister bewust is, sal ik in hope van welduijding overgaan tot de regenten die sig thans bij den vorst soo op panaraga als in het leger aan de rivier Solo bevinden onder de commando van radeen Soerabrata met wien ik Een aanvang sal maken als Een der voornaamste persoonagien en van wiens getrouwheijd den vorst volkomen kan verseeckerd sijn, soo ten aansien van de haat, die hij radeen adepattij toedraagt over de geleden hoon hem aangedaan als ten opzigte der verkiesing van den Keijser die Een van meerm. Tommongong Soerabrata's dogters ten bijwijve heeft genomen .......

Uijt dese en meer andere omstandigheden genoegsaam kunnende afnemen dat meerm. radeen tommongong Soerabrata die weijnig Bereijkt en onveranderlijk in sijn Besluijten valt niet ligt te bewegen sou sijn Een derde attacque te wagen nog in het vertrek van den soesoehoenang te condescendeeren om reden bij mijn dagelijxe aanteeckeningen aangehaald; oversulx ik dan met de bij mij hebbende Europ. besloot van panaraga na Sourabaija te vertrecken ter voldoening van den Keijser die mij instantig versogt UEd.agtb. mondeling te willen bedeelen den beklaaglijken staat waarin hij zig bevond en als een gem. Javaan genoodsaakt waar sig in het panaragase gebergte te verbergen te meer terwijl hij geen antwoord bequam op den Brieff van den 28 Julij aan 
UEd.agtb. van Cadoean gecarteerd, die ik op het versoek van sijn majt. in het maleijds dicteerde en door den Javaan marta diwongsa in dies Tale ten papiere liet stellen waarbij hij de Comp. alle voldoening aanbood en tot Een blijk zijner welmeentheijd genegen was soodanige contracten met deselve te sluijten als men hem sou komen voor te schrijven gelijk ik sulx (des noods sijnde) nevens den vaandrig hogewits en den Scriba Toutelemonde met Eede sou kunnen sterken en opdat UEd.agtb. des te meer gelooff aan sijn beloften mogten slaan versogt hij mijn ter dier tijd UEd.agtb. hiervan Eijgenhandig te willen verseeckeren, welker instantien sijn hoogheijd op mijn vertreck van panaraga wederom herhaalde in het bijsijn van radeen aria pringalaija en wel met deze omstandigheijd, wanneer hij sig niet in staat mogt bevinden d'oncosten van den oorlog in contanten aan de Comp. te kunnen voldoen als dan genegen was tot Een Equivalent van sijn landen aan deselve af te staan, dog dat syn majt. niet gaarne soude sien den pangerang tjacraningrat van madura de door hem bereijds geconquestreerde regentschappen in Eijgendom wierden toegevoegt uijt vrees van sijn heerszugtigen aart en den haat die hij hem toedroeg. 's Keijsers aanbieding van contanten als eene loose belofte aanmerkende, nam ik de vrijheijd sijn hoogheijd te vragen waar hij die penn. van daan sou halen vermits hij immers al het sijnige had verloren waarop sijn majesteijt mij in antwoord diende onderrigt te sijn, dat op pacalongan en de lembarauwen zoo veel geld van radeen adepattij verburgen was, dat dies schatten genoegsaam konden strecken tot voldoening van de

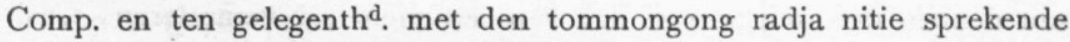
over 's keijsers standvastigh ${ }^{\mathrm{d}}$. en geringe aandoeninge sijner tijdelijke goederen, verhaalde mij denselven seer wel te weten dat in de mattaram volgens d'aloude gebruijken der Javase keijsers geld wierd opgelegt en bewaart, inselver voegen onderstont $\mathrm{ik}$ mij sijn maj ${ }^{t} \mathrm{t}^{\prime}$ onderhouden over de verdere presentatie en sloeg hem voor off het de noodsaackelijkheijd niet soude vereijsschen sijn hooghd. tommongong Tirta wigoena als sijn gesant kennis gav van sijn wil en begeerte invoegen als sijn hoogh ${ }^{d}$ mij die mondeling had gelieven te bedeelen, waarop den vorst repliceerde dat hij tirtawigoena voor desen veel vertrouwd had, maar thans niet wist hoedanig denzelven gesind was en men de menschen wel in d'oogen konde sien maar niet int hert, waarom hij mij versogt sijn aanbiedingen in secretesse aan d'Ed. agtb. te bedeelen opdat sulx niet rugtbaar wierd en aanleijding gaff tot versterking der rebellige parthij dewijl sijn majt. door ondervinding had geleerd wat staat hij op de Javanen int algemeen konde maken en dierhalven met sijn herstelling op de mattaramse throon de hoge Indiese Regeering wilde versoeken Een grooter lijfwagt voor betaling te erlangen, mitsg s. sijn residentiestad nader bij Samarang te stigten en verders den na Ceijlon gesonden danoredja wederom als rijxbestierder aangesteld mogt werden bij aldien de Comp. daar niets 
tegen had; wanneer UEd. agtb. nu eens met opmerking gelieven te Betragten hetgene ik d'Eer heb alhier na gemoede ter neder te stellen zoo twijffel ik niet of UEd.agtb. sullen bevinden dat den rijxbestierder niet alleen de wesentlijke oorsaak is der onheijlen van het Javase rijk, sedert het opbreken desselvs leger van patterongang maar ook te gelijk getragt heevt sig tot keijser op te werpen, gelijk UEd.agtb. hebben kunnen b'oogen uyt d'Eygen bekentenis van den tommongong radja nitie bij mijn dagelijxe anteeckeningen g'insereert, mitsg. uijt het gedane versoek van martapoera die sijn majt. om vergiffenis bad en rondborstig beleed niet anders dan d'orders van den rijxbestierders te hebben volbragt in verbeelding dat het bevelen van zijn hoogh ${ }^{\mathrm{d}}$. waren maar om UEd.agtb. niet langer op te houden met hetgeen waarvan ik selv oor- en ooggetuijge Ben geweest soo sal ik overgaan tot mijne geringe consideratien wegens de slegte gesteldheijd van den keijser en van wat schadelijke gevolgen die somtijds sou kunnen sijn bij aldien de Comp. hem niet ten Eersten te huip komt, nademaal ik niet gelooff dat sourabrata hoe genegen hij den vorst ook is, iets sonderlings sal durven ondernemen sonder adsistentie van de Comp. waardoor den aanhang der Chinesen en rebelleerende Javanen dagelijx versuceerded en het land tot Eene verwoestinge staat gebragt te werden, wat aanbieding quepanjang met mangononeng en maas brahim aan de vorst hebben gedaan en op wat wijse sijn hoogheijd die heeft afgeslagen staan breedvoerig vervat bij het meer geciteerde dagregister, waaraan ik mij kortheijdshalven gedrage om eerlijk hier nog $\mathrm{Bij}$ te voegen, dat ik niet kan denken den keijser soo ligt van sestiment sal veranderen, tensij hij ontwaard geen hulp van de Comp. te sullen Erlangen, wanneer het alsdan wel sou kunnen gebeuren sijn majt. uijt wanhoop Een van beijde de presentatien accepteerde, waaruijt na mijn gedagten wederom Een hevigen en langduurigen oorlog sou kunnen voortvloeijen, daar men tegenwoordig met een geringe magt geconjungeert met den aanhang van den keijser seer schielijk Een Eijnde aan de Javase troubelen sou kunnen maken; alhoewel ik mij seer geerne het wijser oordeel van UEd. agtb. wil onderwerpen die geen ander doelwit in het opstellen deser heb betragt dan de waarheijd en het welsijn van de E. Comp voor soo verre mij die bekend is, waardoor ik mij verbeel te gelijk aan mijn pligt ten aansien der commissie en in voldoening Uwer Ed. agtb. hoog g'Eerd requisit voldaan te hebben, oversulx ik d'Eer heb mij met diep schuldige Eerbied t'onderschrijven.

onderstond (titul) (lager) UEd.agtb. onderdanige en seer gehoorsame dienaren (was get.) J. A. v. hohendorff

(in margine) Samarang den 27 Aug. 1742

(daaronder) accordeert (get.) S. van Suchtelen. Comm. Secrs. 